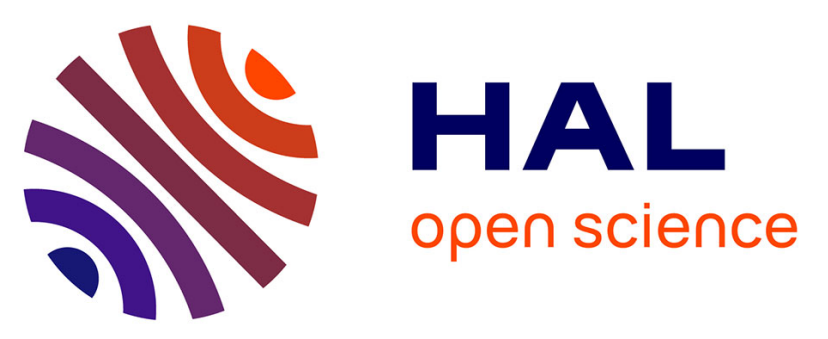

\title{
Trace metal concentrations in post-hatching cuttlefish Sepia officinalis and consequences of dissolved zinc exposure
}

Charles Le Pabic, Christelle Caplat, Jean-Paul Lehodey, Thomas

Milinkovitch, Noussithé Kouéta, Richard Philippe Cosson, Paco Bustamante

\section{To cite this version:}

Charles Le Pabic, Christelle Caplat, Jean-Paul Lehodey, Thomas Milinkovitch, Noussithé Kouéta, et al.. Trace metal concentrations in post-hatching cuttlefish Sepia officinalis and consequences of dissolved zinc exposure. Aquatic Toxicology, 2015, 159, pp.23-35. 10.1016/j.aquatox.2014.11.012 . hal-01119162

\author{
HAL Id: hal-01119162 \\ https://hal.science/hal-01119162
}

Submitted on 23 Feb 2015

HAL is a multi-disciplinary open access archive for the deposit and dissemination of scientific research documents, whether they are published or not. The documents may come from teaching and research institutions in France or abroad, or from public or private research centers.
L'archive ouverte pluridisciplinaire HAL, est destinée au dépôt et à la diffusion de documents scientifiques de niveau recherche, publiés ou non, émanant des établissements d'enseignement et de recherche français ou étrangers, des laboratoires publics ou privés. 


\section{Trace metal concentrations in post-hatching cuttlefish Sepia officinalis and consequences of dissolved zinc exposure}

Charles Le Pabic ${ }^{\mathrm{a}, \mathrm{b}, \mathrm{c}}$, Christelle Caplat ${ }^{\mathrm{a}, \mathrm{b}, \mathrm{c}}$, Jean-Paul Lehodey ${ }^{\mathrm{a}, \mathrm{b}, \mathrm{c}}$, Thomas Milinkovitch ${ }^{\mathrm{d}}$, Noussithé Kouéta $^{\mathrm{a}, \mathrm{b}, \mathrm{c}}$, Richard Philippe Cosson ${ }^{\mathrm{e}}$, Paco Bustamante $^{\mathrm{d}}$

a Normandie Université, F-14032 Caen, France

${ }^{\mathrm{b}}$ UMR BOREA, MNHN, UPMC, UCBN, CNRS-7208, IRD-207, IBFA Université de Caen Basse-Normandie, Esplanade de la Paix, CS 14032, 14032 Caen cedex, France

${ }^{\mathrm{c}}$ Centre de Recherches en Environnement Côtier, Université de Caen Basse-Normandie, 54 rue du Docteur Charcot, 14530 Luc-sur-Mer, France

${ }^{\mathrm{d}}$ Littoral Environnement et Sociétés (LIENSs), UMR 7266 CNRS-Université La Rochelle, 2 rue Olympe de Gouges, 17000 La Rochelle, France

e Mer Molécules Santé (MMS), Université de Nantes, EA 2663, 2 rue de la Houssinière, 44322 Nantes, France

*Corresponding author: Charles Le Pabic

UMR BOREA, MNHN, UPMC, UCBN, CNRS-7208, IRD-207, IBFA Université de Caen Basse-Normandie, Esplanade de la Paix, CS 14032, 14032 Caen cedex, France

Tel.: (+33) 231565102

Fax: (+33) 231565346

e-mail : charles.lepabic@gmx.fr 


\section{Abstract}

In this study, we investigated the changes of 13 trace metal and metalloid concentrations (i.e. $\mathrm{Ag}, \mathrm{As}, \mathrm{Cd}, \mathrm{Co}, \mathrm{Cr}, \mathrm{Cu}, \mathrm{Fe}, \mathrm{Mn}, \mathrm{Ni}, \mathrm{Pb}, \mathrm{Se}, \mathrm{V}, \mathrm{Zn}$ ) and their subcellular fractionation in juvenile cuttlefish Sepia officinalis reared in controlled conditions between hatching and 2-months post-hatching. In parallel, metallothionein concentrations were determined. Our results highlighted contrasting changes of studied metals. Indeed, As and Fe concentrations measured in hatchlings suggested a maternal transfer of these elements in cuttlefish. The non-essential elements $\mathrm{Ag}$ and $\mathrm{Cd}$ presented the highest accumulation during our study, correlated with the digestive gland maturation. During the 6 first weeks of study, soluble fractions of most of essential trace metals (i.e. $\mathrm{Co}, \mathrm{Cr}, \mathrm{Cu}, \mathrm{Fe}, \mathrm{Se}, \mathrm{Zn}$ ) slowly increased consistently with the progressive needs of cuttlefish metabolism during this period. In order to determine for the first time in a cephalopod how metal concentrations and their subcellular distributions are impacted when trace metal exposed, we studied previously described parameters in juveniles exposed to dissolved $\mathrm{Zn}$ at environmental (i.e. $50 \mu \mathrm{g}$ 1-1) and sublethal (i.e. $200 \mu \mathrm{g}$ 1-1) levels. Moreover, oxidative stress (i.e. glutathione Stransferases (GST), superoxide dismutase (SOD), catalase, lipid peroxidation (LPO)) was assessed in digestive gland and gills after 1 and 2 months exposures. Our results highlighted no or low ability of this stage of life to regulate dissolved $\mathrm{Zn}$ accumulation during all studied period, consistently with high sensitivity of this organism. Notably, $\mathrm{Zn}$ exposures caused a dose-dependent Mn depletion in juvenile cuttlefish, and an increase of soluble fraction of Ag, $\mathrm{Cd}, \mathrm{Cu}$ without accumulation modifications, suggesting substitution of these elements (i.e. $\mathrm{Mn}, \mathrm{Ag}, \mathrm{Cd}, \mathrm{Cu}$ ) by $\mathrm{Zn}$. In parallel, metallothionein concentrations decreased in individuals the most exposed to $\mathrm{Zn}$. Finally, no perturbations in oxidative stress management were detected in gills, whereas level modifications of GST, SOD and catalase activities were recorded in digestive gland, resulting in LPO content increase after 6-week exposure at low 
Zn concentration. Altogether, these perturbations are consistent with previously described high sensitivity of juvenile cuttlefish towards $\mathrm{Zn}$. Our results underlined the need to study deeply contamination impact on this animal at this stage of life.

Keywords: mollusk cephalopod; juvenile stage; zinc; metal subcellular distribution; oxidative stress; Sepia officinalis

\section{Highlights}

- Important changes of metal concentrations occurred in cuttlefish after hatching.

- During the 6-weeks post-hatching, metallothionein synthesis was important.

- Juvenile cuttlefish showed low ability to regulate dissolved zinc accumulation.

- Perturbations of $\mathrm{Ag}, \mathrm{Cd}, \mathrm{Cu}$ and $\mathrm{Mn}$ regulation were induced by zinc exposure.

- $52 \mu \mathrm{g} \mathrm{l}^{-1}$ zinc exposure caused oxidative stress in the cuttlefish digestive gland. 


\section{Introduction}

Mollusk cephalopods are known for their importance in trophic marine ecosystems both as predator and prey (Chouvelon et al., 2011; Clarke, 1996). The economic importance of their fisheries has recently grown worldwide to compensate for finfish stock depletion (Jereb et al., 2005), whereas abundant literature underlines their sensitivity to a wide range of environmental parameters (reviewed in Pierce et al., 2008). Despite growing anthropogenic pressures on marine ecosystems, few studies investigated the potential physiological impacts of contaminants on these organisms (Di Poi et al., 2014, 2013; Lacoue-Labarthe et al., 2010a, 2009c; Sen and Sunlu, 2007). Yet, early life stages (i.e. eggs and juveniles) of economically important cephalopods are likely to be impacted by anthropogenic contaminants because they develop in coastal areas where these compounds are found at relatively high concentrations (Colas, 2011; Pierce et al., 2010). This is the case of the common cuttlefish Sepia officinalis, which is characterized by inshore migration during spring and summer months to reproduce and spawn, and juvenile residence in coastal areas from 1 to 2 months post-hatching to take advantage of prey abundance (Bloor et al., 2013; Boucaud-Camou and Boismery, 1991; Le Goff and Daguzan, 1991). In spite of the shielding properties of the eggshell against metals (Bustamante et al., 2006c, 2004, 2002b; Lacoue-Labarthe et al., 2011, 2010b, 2009b, 2008b), cuttlefish embryos are impacted by low metal concentration exposure (Lacoue-Labarthe et al., 2010a, 2009a). In addition, accumulation in soft tissues of waterborne $\mathrm{Ag}, \mathrm{Cd}$, and $\mathrm{Zn}$ followed by relatively long-term retention was reported in juveniles (Bustamante et al., 2004, 2002b). Surprisingly little is known about the effects of such trace metal exposure on juvenile cuttlefish physiology (Lacoue-Labarthe et al., 2010a, 2009a). ${ }^{1}$

\footnotetext{
${ }^{1}$ Abbreviations: CDNB: 1-chloro-2,4-dinitrobenzene; DPP: differential pulse polarographic analysis; GSH: reduced glutathione; GST: glutathione S-transferase; HMWP: high molecular weight proteins; LPO: lipid peroxidation; MDA: malondialdehyde; MT: metallothionein; PBS: phosphate buffered saline; ROS: reactive oxygen species; SOD: superoxide dismutase.
} 
Despite a short life cycle of 1 to 2 years, Sepia officinalis (as other cephalopods) is known to accumulate various contaminants (e.g. Ansari et al., 2012; Bustamante et al., 2006a, 2006b, 1998; Danis et al., 2005; Miramand and Bentley, 1992). Bioaccumulation of trace metals such as $\mathrm{Ag}, \mathrm{Cd}, \mathrm{Cu}, \mathrm{Fe}$ and $\mathrm{Zn}$ has been reported in the digestive gland, sometimes at very high concentrations (e.g. Bustamante et al., 2006a; Decleir et al., 1978; Martin and Flegal, 1975; Miramand and Bentley, 1992; Schipp and Hevert, 1978). Notably, trace metal accumulation starts after hatching and takes place through the entire life cycle, yet tissuespecific accumulation depends on digestive gland maturation (Miramand et al., 2006). While several studies highlighted the essential role of the digestive gland in the detoxification of trace metal elements in Sepia officinalis and other cephalopods (Bustamante et al., 2008, 2004, 2002b; Lacoue-Labarthe et al., 2009c; Martin and Flegal, 1975; Miramand and Bentley, 1992; Raimundo et al., 2014, 2010), no study investigated metal subcellular fractionation at juvenile stages during maturation of this organ (i.e. the first month post-hatching).

Detoxification mechanisms of marine invertebrates mainly involve the precipitation of metals into insoluble concretions and the binding to cytosolic proteins, both being interconnected (Wallace et al., 2003; Wang and Rainbow, 2010). Metallothioneins (MTs) are one class of these metal-binding proteins, characterized by low molecular weight, high cystein content and heat stability. They play a role in the homeostasis of the essential metals, $\mathrm{Cu}$ and $\mathrm{Zn}$, but can be induced by various other metals (e.g. $\mathrm{Ag}, \mathrm{Cd}, \mathrm{Hg}$ ) that they bind (Amiard et al., 2006; Cosson, 1991; Wang and Rainbow, 2010). In cephalopods, subcellular distribution of metals in the digestive gland appears to be species- and element-specific, but most studies reported mainly association of $\mathrm{Ag}, \mathrm{Fe}, \mathrm{Mn}, \mathrm{Pb}$ and $\mathrm{Zn}$ with the insoluble fraction, while $\mathrm{Cd}$, $\mathrm{Co}$ and $\mathrm{Cu}$ are mainly associated with the cytosolic fraction (Bustamante et al., 2006a, 2002a; Finger and Smith, 1987; Tanaka et al., 1983). $\mathrm{Cu}$ is also the main element found associated with MTs in the digestive gland of several cephalopod species (Bustamante et al., 2006a; 
Finger and Smith, 1987; Tanaka et al., 1983), whereas results about Ag- and Cd-MT association remain controversial (Bustamante et al., 2006a, 2002a; Finger and Smith, 1987; Tanaka et al., 1983). To date, the MT involvement in the homeostasis of the cephalopod juvenile stage has been investigated once in the squid Loligo forbesii without highlighting its significant role in $\mathrm{Cu}$ and $\mathrm{Zn}$ management (Craig and Overnell, 2003).

Although $\mathrm{Zn}$ is an essential nutrient of living organisms - it is a component of more than 300 enzymes and other proteins (McCall et al., 2000), some studies highlighted its toxicity in marine organisms at concentrations of $100 \mu \mathrm{g} \mathrm{l}^{-1}$ and above (e.g. Amado Filho et al., 1997; Brereton et al., 1973; Nadella et al., 2013; Tellis et al., 2014; Watling, 1982). In European marine waters, dissolved $\mathrm{Zn}$ is relatively concentrated, regularly measured near 10 $\mu \mathrm{g} \mathrm{l}^{-1}$ (Lachambre and Fisson, 2007a; Sheahan et al., 2007), and worldwide, some studies reported concentrations reaching several hundred $\mu \mathrm{g} \mathrm{Zn} \mathrm{I}^{-1}$ in anthropically impacted bays, gulfs and estuaries (Amado Filho et al., 1997; Liu and Wang, 2013; Srinivasa Reddy et al., 2005). $\mathrm{Zn}$ is also one of the most concentrated metals in the digestive gland of cuttlefish (Bustamante et al., 2006a; Miramand and Bentley, 1992; Miramand et al., 2006; Rjeibi et al., 2014). Its effects on the uptake of other metals, their subcellular distribution, and MT concentrations have been highligthed in bivalve mollusks (Blackmore and Wang, 2002; Hennig, 1986; Lemoine et al., 2000; Liu and Wang, 2013; Shi and Wang, 2004). For instance, $\mathrm{Zn}$ exposure induced an increase in $\mathrm{Zn}$ uptake as well as that of $\mathrm{Cd}$ and $\mathrm{Cu}$ in the bivalve Crassostrea hongkongensis (Liu and Wang, 2013). To the best of our knowledge, such responses have not been assayed in cephalopods. Finally, trace metals are known for their ability to induce reactive oxygen species (ROS) production, causing oxidative stress as previously described in bivalves (e.g. Company et al., 2004; Funes et al., 2006; Geret and Cosson, 2002; Geret et al., 2002), gastropods (Chandran et al., 2005; Malanga et al., 2004; Radwan et al., 2010) and the cephalopod Octopus vulgaris (Semedo et al., 2012). To avoid or 
counteract ROS effects, organisms use a set of enzymes including glutathione S-transferases (EC 2.5.1.18, GST), superoxide dismutase (EC 1.15.1.1, SOD) and catalase (EC 1.11.1.6). Their activities have been extensively used as biomarkers of oxidative stress, and correlated to the presence of metals in invertebrates (e.g. Regoli and Principato, 1995; Semedo et al., 2012; Vlahogianni et al., 2007). The imbalance between production and removal of ROS may result in lipid peroxidation (LPO), a biomarker often used to evaluate the degree of oxidative stress (e.g. Di Salvatore et al., 2013; Radwan et al., 2010; Vlahogianni et al., 2007; Zielinski and Pörtner, 2000).

In order to better describe and understand metal regulation in juvenile cuttlefish and point out the effect of physiological modifications on the bioaccumulation and detoxification processes associated with digestive gland maturation, we quantified the presence, changes of the concentrations and the subcellular distributions of 13 elements $(\mathrm{Ag}, \mathrm{As}, \mathrm{Cd}, \mathrm{Co}, \mathrm{Cr}, \mathrm{Cu}$, $\mathrm{Fe}, \mathrm{Mn}, \mathrm{Ni}, \mathrm{Pb}, \mathrm{Se}, \mathrm{V}$, and $\mathrm{Zn}$ ) in juvenile cuttlefish during the period corresponding to their coastal life stage (i.e. first 2 months post-hatching). The concentration of MTs was also assayed and correlated with metal concentration modifications. Concurrently, these parameters were measured under $\mathrm{Zn}$-exposure, in addition to oxidative stress parameters (GST, SOD, catalase, and LPO) in the digestive gland and in the gills which are the tissue directly in contact with food and waterborne trace elements, respectively.

\section{Materials and methods}

\subsection{Animals}

Cuttlefish eggs were collected from traps set along the Calvados coast (BasseNormandie, France) during summer 2012. All rearing procedures were held at the Centre de Recherches en Environnement Côtier (Luc-sur-Mer, France). At the laboratory, the eggs were separated for optimal oxygenation, acclimatized at $17 \pm 1^{\circ} \mathrm{C}$, and maintain in open-circuit 
tanks until hatching. Between 1 and 2 day post-hatching, juveniles were randomly acclimatized in experimental structures and fed $24 \mathrm{~h}$ later according to hatchling vitellus consumption period (Yim and Boucaud-Camou, 1980). During all experiment, cuttlefish were fed once a day with alive brown shrimp Crangon crangon fished every 2 days in front of the marine station. In order to obtain homogeneous intra- and inter-batch growth, the number of prey was adapted to the cuttlefish size and special attention was payed daily to feed all animals (in control as well as Zn-exposed conditions) with shrimps of the same size range.

\subsection{Experimental design}

\subsubsection{Experimental system and seawater quality follow-up}

To allow individual follow-up, constant exposure, as well as long-term water quality (particularly considering nitrogen compounds), we set up experimental units described below. In a 40-1 tank (corresponding to one experimental unit), seawater mixing and oxygenation were provided by 2 water pumps (NJ400, Aquarium systems, France) and 2 air stones. A constant water renewal was provided in each experimental unit by peristaltic pump (521F/D2, Watson-Marlow Pumps Group, France), supplied with frequency converter and pumpheads (312X2, Watson-Marlow Pumps Group, France), at a rate of $30 \mathrm{ml} \mathrm{min}^{-1}$ from $60-1$ reservoirs. Water used during all experiments was decanted charcoal-filtered natural seawater to minimize particles and other dissolved metals attendance. Depending on renewal rate, reservoirs were refilled each day with seawater (either Zn-contaminated or control). In order to avoid animal interactions and to allow individual follow-up, a compartmentalized sieve was used. Each compartment had an area of $104 \mathrm{~cm}^{2}$, which is enough space for optimal development of single juvenile according to Forsythe et al. (1994). During all experiments, seawater parameter monitoring was checked daily. Parameter variations for all experimental structures were: temperature: $17.5 \pm 0.5^{\circ} \mathrm{C}$; salinity: $32.5 \pm 1 \mathrm{psu}$; ammonia-, nitrite-, and 
nitrate-nitrogen below $0.5 \mathrm{mg} \mathrm{l}^{-1}, 0.5 \mathrm{mg} \mathrm{l}^{-1}$, and $80 \mathrm{mg} \mathrm{l}^{-1}$, respectively (according to Oestmann et al. (1997)); pH: $8.0 \pm 0.1$; and dissolved oxygen: > $9 \mathrm{mg} \mathrm{l}^{-1}$. Experiments were realized under natural photoperiod. To keep high water quality, feces were siphoned every 3 days in order to reduce juvenile disturbance.

\subsubsection{Zn-exposures and measurements}

During summer 2012 and according to previous studies on mortality induced by dissolved $\mathrm{Zn}$ on juvenile cuttlefish (Le Pabic et al., under review), juvenile cuttlefish were exposed to 50 and $200 \mu \mathrm{g} \mathrm{Zn} 1^{-1}$ (respectively, Z1 and Z2) for 8- and 6-weeks, respectively, alongside a control. Both $\mathrm{Zn}$ concentrations were environmentally realistic, with Z2 corresponding to concentration close to the previously determined mortality threshold value for 2-week post-hatching juvenile cuttlefish (Le Pabic et al., under review). The exposure media were spiked daily just after reservoir water renewal, using $20.84 \mathrm{~g} \mathrm{l}^{-1} \mathrm{ZnCl}_{2}$ (i.e. $10.0 \mathrm{~g}$ $\left.\mathrm{Zn}^{-1}\right)$ stock solution $\left(\mathrm{ZnCl}_{2}\right.$ reagent grade, $\geq 98 \%$, Sigma-Aldrich, France), prepared in 0.22 $\mu$ m-filtered artificial seawater $\left(25.5 \mathrm{~g} \mathrm{NaCl}, 6.4 \mathrm{~g} \mathrm{MgSO}_{4}, 5.2 \mathrm{~g}\right.$ Hepes, $1.5 \mathrm{~g} \mathrm{CaCl}_{2} \cdot 2 \mathrm{H}_{2} \mathrm{O}$, $0.75 \mathrm{~g} \mathrm{KCl}$ in 1 liter Milli-Q water, $\mathrm{pH}$ 7.4). According to preliminary trials, each reservoir was spiked weekly with respective nominal concentration plus $10 \%$ in order to keep constant concentrations and compensate animal absorption and experimental unit adsorption.

For all 3 batches (control and the 2 exposure conditions), $20 \mathrm{ml}$ of seawater was sampled daily, immediately acidifed with $1 \%$ nitric acid $\left(\mathrm{HNO}_{3} 69.5 \%\right.$, Normapur grade), and stored at $4{ }^{\circ} \mathrm{C}$ until analyses. $\mathrm{Zn}$ concentrations in the seawater were determined as previously described in Devos et al. (2012). Triplicate analyses were done on each sample and the mean values were used for evaluation. The limit of detection, defined as the background plus three times the standard deviation of the blank $(3 \sigma)$, for the determination of the $\mathrm{Zn}$ concentration in seawater was $6.2 \mu \mathrm{g}^{-1}$. 


\subsubsection{Sampling procedure}

All samplings were performed on 24-h fasting animals. Considering the elemental concentration assays, 9 animals were sampled at the beginning of the experiment, thereafter 5 animals from each batches were randomly removed every 2 -weeks exposure (i.e. after 2-, 4-, 6- and 8-weeks). According to organ size, samplings dedicated to enzymatic assays were realized with 5 animals per conditions after 4-week exposure in Z2, and 4-, 6- and 8-week exposure in control and Z1 conditions. All animals sampled were anesthetized in solution of $2 \%$ ethanol with $17.5 \mathrm{mg} \mathrm{l}^{-1} \mathrm{MgCl}_{2}$ in seawater for $5 \mathrm{~min}$, afterwards they were measured (weight and mantle length). Individuals dedicated to elemental analysis were immediately frozen in liquid nitrogen, whereas the digestive glands and the gills were sampled on animals with cephalopodium (i.e. head, arms and funnel) preliminary removed (Di Poi et al., 2014). Tissues were then frozen in liquid nitrogen and stored at $-80^{\circ} \mathrm{C}$ for enzymatic assay, whereas whole animals were freeze-dried and individually ground for MTs and trace element analysis.

\subsection{Subcellular fractionation and MT determination}

Whole cuttlefish were analysed for their MT levels. Between 30 and $100 \mathrm{mg}$ of ground dry tissue were homogenized on ice in 4-6 ml (depending of aliquot size) $100 \mathrm{mM}$ Tris buffer with $\beta$-mercaptoethanol at $\mathrm{pH} 8.1$ and then centrifuged $\left(30000 \mathrm{~g} ; 30 \mathrm{~min} ; 4^{\circ} \mathrm{C}\right)$. Around 100 $\mu 1$ of supernatants were used for MT assay, while pellets (i.e. the insoluble fraction) and the remaining supernatant (i.e. the soluble fraction) were stored frozen for further trace element analysis. The supernatant aliquot was then submitted to protocol described in Lucia et al. (2012) in order to obtain heat-stable protein fraction. Finally, differential pulse polarographic analysis (DPP) was used to determine the amount of MTs in this fraction and set up as described in Lucia et al. (2012). Results are expressed in $\mu \mathrm{g}$ of MTs per g of dry homogenized 
tissue $\left(\mu \mathrm{g} \mathrm{g}^{-1} \mathrm{dw}\right)$.

\subsection{Trace element analysis in respective soluble and insoluble fractions}

For the analysis of all elements (i.e. $\mathrm{Ag}, \mathrm{As}, \mathrm{Cd}, \mathrm{Co}, \mathrm{Cr}, \mathrm{Cu}, \mathrm{Fe}, \mathrm{Mn}, \mathrm{Ni}, \mathrm{Pb}, \mathrm{Se}, \mathrm{V}$ and $\mathrm{Zn}$ ), from 50 to $300 \mathrm{mg}$ of each subcellular fractions were digested following protocol described in Metian et al. (2008).

Trace elements were analysed by Inductively Coupled Plasma Atomic Emission Spectrometry (Varian Vista-Pro ICP-OES) and Mass Spectrometry (ICP-MS II Series Thermo Fisher Scientific). Reference tissues - dogfish liver DOLT-4 (NRCC), lobster hepatopancreas TORT-2 (NRCC) - were treated and analysed in the same way as the samples. Results were in line with the certified values, and the standard deviations were low, proving good repeatability of the method. The results for standard reference materials displayed recovery of the elements ranging from $73 \%$ to $114 \%$. The detection limits $\left(\mu \mathrm{g} \mathrm{g}^{-1} \mathrm{dw}\right)$ were $0.015(\mathrm{Cd})$, $0.017(\mathrm{Ag}), 0.02(\mathrm{Co}, \mathrm{Cr}, \mathrm{Pb}), 0.03(\mathrm{Ni}), 0.08(\mathrm{Mn}), 0.1(\mathrm{Cu}, \mathrm{Se}), 0.2(\mathrm{As}), 0.3(\mathrm{~V})$ and $3.3(\mathrm{Fe}$ and $\mathrm{Zn})$. Trace element concentrations are expressed in $\mu \mathrm{g} \mathrm{g}^{-1} \mathrm{dw}$.

\subsection{Biochemical analysis}

Sampled digestive glands and gills of one animal were separately weighed before to be homogenized with a Potter-Elvehjem homogeniser in ice-cold phosphate buffered saline (500 $\mathrm{mM} \mathrm{NaCl}, 10 \mathrm{mM} \mathrm{Na}_{2} \mathrm{HPO}_{4}$ and $\left.3.1 \mathrm{mM} \mathrm{KH}_{2} \mathrm{PO}_{4}, \mathrm{pH} 7.4, \mathrm{PBS}\right)$ containing $1 \%$ Halt Protease Inhibitor Cocktail, EDTA-Free (100X, Thermo Fisher Scientific, Waltham, USA). Weight/volume ratio of $1 / 2$ and $1 / 1$ was used for digestive gland and gills, respectively. Homogenates were then centrifuged at $12,500 \mathrm{~g}$ for $15 \mathrm{~min}$ at $4{ }^{\circ} \mathrm{C}$ ( $\mathrm{S} 9$ fraction), and supernatants used for determining protein content, LPO, as well as enzymatic activities (GST, 
SOD, catalase). All these analyses were adapted for microplate and realized in triplicate for each individual.

\subsubsection{Protein assay}

Total protein concentration was determined according to the Bradford method (1976) using bovine serum albumin (Sigma-Aldrich Chemicals, France) as standard. Enzymatic activities and LPO were expressed in relation to protein concentration measured in S9 fraction.

\subsubsection{GST assay}

GST activity was measured according to the Habig et al. method (1974). Briefly, $50 \mu 1$ of S9 fraction adjusted to $250 \mu \mathrm{g}$ prot $\mathrm{ml}^{-1}$ in PBS were mixed with $200 \mu \mathrm{l}$ of reagent solution (1 mM reduced glutathione (GSH), $10 \mathrm{mM}$ Hepes, $125 \mathrm{mM} \mathrm{NaCl}$, and $1 \mathrm{mM}$ 1-chloro-2,4dinitrobenzene (CDNB), pH 6.5). The enzymatic reaction kinetic was spectrophotometrically monitored at $340 \mathrm{~nm}$ for $20 \mathrm{~min}$ at $25^{\circ} \mathrm{C}$. The results were expressed as $\mu \mathrm{mol}$ of glutathioneCDNB conjugates per min and $\mathrm{mg}$ of proteins $\left(\mu \mathrm{mol} \mathrm{min}{ }^{-1} \mathrm{mg}^{-1} \mathrm{prot}\right)$.

\subsubsection{SOD assay}

SOD activity was measured using the assay developed by Paoletti et al. (1986) and adapted for microplate. A SOD standard (Sigma-Aldrich Chemicals, France) range from 2.5 to $10 \mathrm{U} \mathrm{ml}^{-1}$ was made in PBS. The inhibition of $\beta-\mathrm{NADH}$ (Sigma-Aldrich Chemicals, France) oxidation was then monitored at $340 \mathrm{~nm}$ for $90 \mathrm{~min}$ at $25^{\circ} \mathrm{C}$ using $20 \mu \mathrm{l}$ of $\mathrm{S} 9$ fraction adjusted to $150 \mu \mathrm{g}$ prot $\mathrm{ml}^{-1}$ in PBS, or SOD standard, mixed with $173 \mu \mathrm{l}$ of $0.35 \mathrm{mM} \mathrm{B-}$ NADH, $6 \mathrm{mM}$ EDTA and $3 \mathrm{mM} \mathrm{MnCl}_{2}$, and $20 \mu \mathrm{l}$ of $10 \mathrm{mM} \beta$-mercaptoethanol (SigmaAldrich Chemicals, France). The results were expressed in $\mathrm{U} \mathrm{mg}^{-1}$ of protein. 


\subsubsection{Catalase assay}

Catalase activity was monitored using the method previously described by Babo and Vasseur (1992). A catalase standard (Sigma-Aldrich Chemicals, France) range from 1 to $6 \mathrm{U}$ $\mathrm{ml}^{-1}$ was made in PBS. Then, $100 \mu \mathrm{l}$ of S9 fraction (adjusted respectively to 1.5 and $1.0 \mathrm{mg}$ prot $\mathrm{ml}^{-1}$ in PBS for digestive gland and gills) or catalase standard were mixed with $100 \mu \mathrm{l}$ of hydrogen peroxyde $28 \mathrm{mM}$. The hydrogen peroxyde degradation kinetics were assessed at $240 \mathrm{~nm}$ for $15 \mathrm{~min}$ at $25^{\circ} \mathrm{C}$ in UV microplate (Greiner Bio-One, Germany), and the results were expressed in $\mathrm{U} \mathrm{mg}^{-1}$ of protein.

\subsubsection{LPO determination}

Lipid peroxidation level was assessed via malondialdehyde (MDA) content determined using a commercially available MDA assay kit (Oxis International, USA). The method was based on the reaction of a chromogenic reagent, N-methyl-2-phenylindole, with $\mathrm{MDA}$ at $45^{\circ} \mathrm{C}$. The blue product was quantified by measuring absorbance at $586 \mathrm{~nm}$ (GérardMonnier et al., 1998). The results were expressed in nmol MDA g ${ }^{-1}$ of protein.

\subsection{Statistical analysis}

To study the changes of each variables function of time, their homogeneity of variances (Levene test) and normal residual distributions (Shapiro test) were first tested. According to the results, ANOVA or permutational ANOVA (in case of non normal residuals) followed by non parametric pairwise permutational $t$-test $(N<30)$ were realized. In case of variance non-homogeneity, Kruskal-Wallis test followed by the Wilcoxon signed-rank were used. In some cases, logarithmic (Log; As total concentration) or reciprocal (Fe total concentration) were used to meet the underlying assumptions of normality and homogeneity 
of variances. Pearson and Spearman correlations, respectively between soluble and insoluble concentrations of trace metals, were analyzed according to data binormality assumption. Comparisons between variables from control and $\mathrm{Zn}$ exposed individuals were realized using ANCOVA when data profiles were linear (i.e. MTs, Mn total concentration, GST activity). In the case of MT comparison, a square transformation was used to realized this test. Otherwise, comparison with control was assessed at each time-point using Student's $t$-test. R software and packages were used for statistics and graphics (Fox and Weisberg, 2011; Hervé, 2012; R Core Team, 2012).

\section{Results}

No mortality occured during this experiment.

\subsection{Trace metal in juvenile cuttlefish}

In this study, the soluble and insoluble amounts of trace metals as well as the MT content were measured in each animal.

\subsubsection{Variation of the trace metal concentration}

In order to study metal regulation in healthy juveniles, the concentration of 13 trace elements was assayed in whole juvenile cuttlefish directly after hatching and at 2-, 4-, 6- and 8-week post-hatching (Table 1). Trace element concentrations were grouped together according to their changes in whole juvenile cuttlefish between hatching time and 8 weeks. During this period, the total concentration of 5 elements decreased (As, $\mathrm{Cr}, \mathrm{Fe}, \mathrm{Mn}$ and $\mathrm{Ni}$ ), while it increased for 4 elements ( $\mathrm{Ag}, \mathrm{Cd}, \mathrm{Cu}$ and $\mathrm{Se})$, remained constant for 3 elements (Co, $\mathrm{Pb}$ and $\mathrm{Zn}$ ) and stayed below the detection limit for $\mathrm{V}$. Among decreasing elements, As and Fe displayed the highest concentrations found in the hatchlings $\left(176 \pm 76\right.$ and $103 \pm 71 \mu \mathrm{g} \mathrm{g}^{-1}$ $\mathrm{dw}$, respectively), whereas $\mathrm{Cr}, \mathrm{Mn}$ and Ni displayed the lowest concentrations of $1.87 \pm 0.36$, $2.67 \pm 0.36$ and $1.71 \pm 0.46 \mu \mathrm{g} \mathrm{g}^{-1} \mathrm{dw}$, respectively. This decreasing phase mainly occurred 
between hatching time and the $6^{\text {th }}$ week for all these elements, reaching $55.8 \pm 9.4$, less than $0.28,25.3 \pm 4.1,1.95 \pm 0.1$ and $1.06 \pm 0.08 \mu \mathrm{g} \mathrm{g}^{-1} \mathrm{dw}$, respectively for As, Cr, Fe, Mn and Ni. Among increasing elements, the $\mathrm{Cu}$ increase occurred during the 2 first weeks (from $47.2 \pm$ 5.0 to $59.3 \pm 3.1 \mu \mathrm{g} \mathrm{g}^{-1} \mathrm{dw}$ ) afterwards its concentration remained constant. Although increasing, Se concentration did not present clear pattern of change during the period (ranging between $1.81 \pm 0.21$ and $2.64 \pm 0.05 \mu \mathrm{g} \mathrm{g}^{-1} \mathrm{dw}$ ). During the first month of the study, the nonessential elements $\mathrm{Ag}$ and $\mathrm{Cd}$ presented an important accumulation from values lower than $0.1 \mu \mathrm{g} \mathrm{g}^{-1} \mathrm{dw}$ in hatchlings for both elements to $2.09 \pm 0.22$ and $0.39 \pm 0.06 \mu \mathrm{g} \mathrm{g}^{-1} \mathrm{dw}$, respectively at 1 month post-hatching, afterwards their concentrations remained stable. During all the studied period, $\mathrm{Co}, \mathrm{Pb}$ and $\mathrm{Zn}$ concentrations remained constant around $0.21 \pm$ $0.04,0.41 \pm 0.12$ and $88.3 \pm 7.8 \mu \mathrm{g} \mathrm{g}^{-1} \mathrm{dw}$, respectively.

\subsubsection{Variation of the subcellular distribution}

To better understand the change of subcellular fractions of trace metals in juveniles during the first 2 months post-hatching, soluble trace elements were assayed as the proportion of the total content between hatching and 2 month post-hatching in whole animals (Table 2). During this period, the subcellular distributions of $\mathrm{As}, \mathrm{Cd}, \mathrm{Mn}, \mathrm{Ni}$ and $\mathrm{Pb}$ remained constants at around $93.0 \pm 1.5,28.2 \pm 4.2,36.5 \pm 7.8,75.9 \pm 6.0$ and $77.9 \pm 5.5 \%$ in the soluble fraction, respectively. Soluble Ag distribution alone decreased significantly, from $10.4 \pm 1.7$ to $7.4 \pm 0.6 \%$ between 2 and 6 weeks. In contrast, the distribution of soluble $\mathrm{Co}, \mathrm{Cu}, \mathrm{Fe}$ and Zn increased mainly between hatching and 6 weeks from $49.2 \pm 5.9$ to $74.9 \pm 2.0,27.3 \pm 11.8$ to $55.1 \pm 5.1,14.0 \pm 12.8$ to $48.6 \pm 7.7$ and $14.8 \pm 5.8$ to $26.6 \pm 4.0 \%$, respectively. Our study highlighted that $\mathrm{Ag}, \mathrm{Cd}, \mathrm{Fe}, \mathrm{Mn}$ and $\mathrm{Zn}$ were mainly associated to the insoluble fraction while $\mathrm{As}, \mathrm{Co}, \mathrm{Cr}, \mathrm{Ni}, \mathrm{Pb}$ and $\mathrm{Se}$ were mainly found in the soluble fraction in the whole juvenile cuttlefish. Notably, $\mathrm{Cu}$ was the only element displaying a major proportion as insoluble form 
in the hatchlings, subsequently switching to a majority as soluble form at the end of the study period. The positive correlations between the soluble fractions of all trace elements (Table 3 ) as well as the insoluble fractions (Table 4) allowed at distinguishing 2 groups of elements: $\mathrm{Ag}, \mathrm{Cd}, \mathrm{Co}, \mathrm{Cu}$, and $\mathrm{Zn}$ on one side and $\mathrm{As}, \mathrm{Cr}, \mathrm{Fe}, \mathrm{Mn}$, and $\mathrm{Ni}$ on the other side. Otherwise, soluble and insoluble concentrations of $\mathrm{Pb}$ as well as $\mathrm{Se}$ fell into different correlation groups.

\subsubsection{Variation of MT concentration and correlation with soluble element concentrations}

The MT concentrations were assayed in the heat-stable soluble fraction of whole juveniles during the first 2 months post-hatching (Fig. 1). Its concentrations increased dramatically along the experiment, highlighting an important MT synthesis occurred at this period, particularly during the 6 first weeks post-hatching, which increased from $686 \pm 93$ to $5551 \pm 631 \mu \mathrm{g} \mathrm{g}^{-1} \mathrm{dw}$. During this period, MT concentrations and size (weight and mantle length) had a positive linear correlation ( $\mathrm{r}=0.93$ and 0.90 , respectively, and $p$-values $<0.001$ ). After the $6^{\text {th }}$ week, MT concentrations decreased back to 4-week levels (i.e. $3617 \pm 417 \mu \mathrm{g} \mathrm{g}^{-1}$ $\mathrm{dw})$.

Positive correlations were found between MT concentrations and soluble $\mathrm{Cu}$ and $\mathrm{Zn}$ concentrations ( $\mathrm{r}=0.41$ and $\rho=0.47$, respectively) (Table 3 ).

\subsection{Zn exposures}

Table 5 shows the mean $\mathrm{Zn}$ concentrations during studied period (i.e. 8 and 6 weeks, respectively for $\mathrm{Z} 1$ and $\mathrm{Z} 2$ ) expressed in $\mu \mathrm{g} \mathrm{l}^{-1}$ and $\mu \mathrm{M}$, measured in the seawater of control, $\mathrm{Z} 1$ and $\mathrm{Z} 2$ batches. Table 6 shows the mean concentrations of the studied trace elements in the brown shrimp used as food during the study.

\subsubsection{Elemental concentration perturbations}


The variation of $\mathrm{Zn}$ concentrations in juvenile cuttlefish following the exposure to the waterborne metal is presented in Figure 2. Whereas $\mathrm{Zn}$ concentrations remained constant in control (i.e. $<6.2 \mu \mathrm{g} \mathrm{l}^{-1}$ ), $\mathrm{Zn}$ concentration increased in both conditions with stabilization occurring in $\mathrm{Z} 1$ (i.e. $52 \mu \mathrm{g}^{-1}$ ) after 4-week exposure at $302 \pm 27 \mu \mathrm{g} \mathrm{g}^{-1} \mathrm{dw}$, and a constant increase in $\mathrm{Z} 2$ (i.e. $184 \mu \mathrm{g} \mathrm{l}^{-1}$ ) reaching $959 \pm 132 \mu \mathrm{g} \mathrm{g}^{-1} \mathrm{dw}$ after 6-week exposure (Fig. 2).

Apart from $\mathrm{Zn}$, the only element showing a variation in total concentration was $\mathrm{Mn}$ (Fig. 3). Thus, a dose-dependent decrease of Mn concentration occurred after 2- and 6-week exposure in $\mathrm{Z} 2$ and $\mathrm{Z} 1$ conditions, respectively. ANCOVA analysis highlighted a similar profile (i.e. slope) in the 3 conditions studied but at different concentration levels (i.e. yintercept) for both $\mathrm{Zn}$-exposures ( $p$-value $<0.01$ and 0.001 for $\mathrm{Z} 1$ and $\mathrm{Z} 2$, respectively).

\subsubsection{Variation of subcellular distribution}

The exposure to waterborne $\mathrm{Zn}$ induced a general increase of the proportion of soluble $\mathrm{Ag}, \mathrm{Cd}, \mathrm{Cu}$ and $\mathrm{Zn}$ (Fig. 4). In Z2, all these elements presented a significant soluble percentage increase regardless of the exposure time of around 2.2-, 2.0-, 1.2- and 1.4-fold the control level for $\mathrm{Ag}, \mathrm{Cd}, \mathrm{Cu}$ and $\mathrm{Zn}$, respectively. Notably, their profiles remained similar to those of the control, and only soluble proportions appeared modified. In Z1, similar increase (towards control condition) of the soluble proportions were measured after 2-week exposure for $\mathrm{Ag}, \mathrm{Cd}$ and $\mathrm{Zn}$, for all elements after 4-week exposure, whereas the soluble proportion of each of these elements was similar to those of the control after 6-week exposure. During the 2 last weeks exposure, whereas $\mathrm{Cd}, \mathrm{Cu}$ and $\mathrm{Zn}$ soluble proportion increased again, $\mathrm{Ag}$ remained similar to the level in the control.

\subsubsection{MT perturbations}


According to the linear profile of MT concentration observed in the control and to the lack of differences between $\mathrm{Z} 1$ and the control conditions after 8-week exposure (data not shown), the general change of this parameter was assayed during the first 6-week period. ANCOVA analysis highlighted no significant difference on MT concentrations at Z1 ( $p$-value $=0.17$ ) compared to control, and significant negative effect at Z2 considering all studied period (i.e. from 0 to 6-week exposure; $p$-value =0.009) $($ Fig. 5).

\subsubsection{Oxidative stress in digestive gland and gills}

Because of the small size of organs and the lack of digestive gland differentiation (in rudimentary form during the first month post-hatching), first samplings were realized after 1month exposure in order to allow individual analysis.

In gills, no effect of Zn exposures on GST, SOD and catalase activities or LPO level were detected, regardless of the exposure time (data not shown). In contrast, some important modifications of these parameters were measured in the digestive gland. Indeed, a significant increase in GST activity was observed in this organ after 4-week exposure to Z2 (Fig. 6) and in Z1 (ANCOVA $p$-value $=0.026$ ). Notably, GST activity also increased in the digestive glands of control individuals during the sampling period. SOD activities increased at each sampling date in Z1 alone (Fig. 6), whereas catalase activities significantly decreased after 4week exposure in Z2, and 6- and 8-week exposure in Z1 (Fig. 6). Finally, LPO presented higher levels after 6- and 8-week exposure in Z1 (Fig. 7). Notably, LPO level in the digestive gland of the control decreased between 4- and 6-week post-hatching.

\section{Discussion}

According to French national monitoring of inshore seawater, the values of dissolved metal concentrations in natural seawater used during this experiment were similar or lower 
than national median concentration except for $\mathrm{Ag}$, with a concentration 4 times higher than national median (ranged 2-4 ng 1-1; Boust et al., 2004; Chiffoleau et al., 2001; Etourneau et al., 2013; Ifremer, 2007; Lachambre and Fisson, 2007b). In order to minimize contamination from both particle and dissolved trace elements, seawater was decanted before being charcoal-filtered.

\subsection{Metal concentrations in juvenile cuttlefish}

Hatchlings presented higher trace element concentrations higher than previously reported in cephalopods for $\mathrm{As}, \mathrm{Cr}, \mathrm{Fe}, \mathrm{Mn}$ and $\mathrm{Ni}$ (Bustamante et al., 2008; Horowitz and Presley, 1977; Ichihashi et al., 2001a, 2001b; Kojadinovic et al., 2011; Miramand and Bentley, 1992; Napoleão et al., 2005; Raimundo et al., 2014, 2010). Among them, As, Fe and to a lesser extent, $\mathrm{Cr}$, displayed the highest concentrations followed by an important decrease during the first 6-weeks post-hatching (Table 1). According to the very important mean content of As and Fe in hatchlings - 176 and $103 \mu \mathrm{g} \mathrm{g}^{-1} \mathrm{dw}$, respectively - and to their low dissolved concentrations in our rearing seawater - around 1 and $5 \mu \mathrm{gl}^{-1}$, respectively (Boust et al., 2004; Lachambre and Fisson, 2007c) -, it is very likely that maternal transfer is the main source for both elements. As and $\mathrm{Fe}$ accumulation was previously reported in cephalopod genital tissues: the oviduct gland of the giant squid Architeuthis dux is the tissue containing the highest As concentration (Bustamante et al., 2008), and high Fe concentrations were found in the genital tract of female cuttlefish from the English channel $\left(173 \pm 14 \mu \mathrm{g} \mathrm{g}^{-1}\right.$ $\mathrm{dw})$ as well as in eggshells from the same location $\left(398 \pm 64 \mu \mathrm{g} \mathrm{g}^{-1} \mathrm{dw}\right.$; Miramand and Bentley, 1992; Miramand et al., 2006). In contrast, low Fe concentration was previously reported in S. officinalis hatchlings from the Mediterranean sea, suggesting an important environmental influence on this process (Villanueva and Bustamante, 2006). Maternel transfer is also likely to be the main source of $\mathrm{Cr}$ found in hatchlings. Indeed, higher $\mathrm{Cr}$ 
concentrations were found in juveniles of the squid Stenoteuthis oualaniensis than in adults (Ichihashi et al., 2001a), and higher Cr concentrations were reported in ovary and genital tract of A. dux and S. officinalis than in other tissues (Bustamante et al., 2008; Miramand and Bentley, 1992). The important decrease in total concentration of As, Fe and $\mathrm{Cr}$ during the 6 first weeks post-hatching suggested excretion of these elements at this period (Table 1).

In spite of their low total concentrations in hatchlings, Mn and Ni values (2.67 and $1.71 \mu \mathrm{g} \mathrm{g}^{-1} \mathrm{dw}$, respectively) were higher than previously reported in whole adult S. officinalis (Miramand and Bentley, 1992). Because of these low numerical values and the previously documented ability of Mn to accumulate in cuttlefish embryos through the eggshell (LacoueLabarthe et al., 2010b), but not through maternal transfer (Lacoue-Labarthe et al., 2008a), high $\mathrm{Mn}$ and Ni likely bioaccumulated from seawater during the egg development. Consistently, the dissolved concentrations of $\mathrm{Mn}$ and $\mathrm{Ni}$ in our rearing seawater was in the upper range of national median range (i.e. around 7 and $2 \mu \mathrm{g} \mathrm{l}^{-1}$ of $\mathrm{Mn}$ and $\mathrm{Ni}$, respectively; Boust et al., 2004; Chiffoleau et al., 2001). The slow and constant total concentration decreases observed during the first 6 weeks post-hatching was very likely the result of dilution by growth (Rainbow and White, 1989) (Fig. 1).

Elements that strongly accumulated in our study were the non-essential elements Ag and $\mathrm{Cd}$, with around 10 - and 4-fold increase, respectively, during the first month posthatching. Interestingly, their concentrations stabilized in subsequent time-points (Table 1), correlating with the time of digestive gland maturation (Yim and Boucaud-Camou, 1980). Previous studies showed that the mature cuttlefish digestive gland contains more than $70 \%$ of the total body content in both elements (Bustamante et al., 2002b; Miramand and Bentley, 1992; Miramand and Guary, 1980; Miramand et al., 2006). Once in this tissue, Ag is quickly excreted whereas $\mathrm{Cd}$ is stored in a less toxic form, mainly associated to cytosolic proteins, allowing to its long-term retention at very high concentrations in the digestive gland 
(Bustamante et al., 2002a, 2002b). Interestingly, the major difference in accumulation processes of these elements between juvenile with non-mature digestive gland and adult is the higher assimilation efficiency by juveniles of contaminants contained in food, as juvenile digestion is mostly intracellular (Bustamante et al., 2004, 2002b; Yim and Boucaud-Camou, 1980).

The only element with a decrease in its soluble fraction during our study was the nonessential trace metal Ag. This decrease occured during the first 6 weeks post-hatching, underlying the set-up of an efficient detoxification pathway of Ag and correlating with the digestive gland maturation which is involved in $\mathrm{Ag}$ insolubilisation (Bustamante et al., 2006a; Martoja and Marcaillou, 1993) (Table 2).

Other elements with a modification of their subcellular fractionation were the essential trace metals $\mathrm{Co}, \mathrm{Cr}, \mathrm{Cu}, \mathrm{Fe}, \mathrm{Se}$ and $\mathrm{Zn}$, with an increase in their soluble proportion (Table 2). All increases occurred during the first 4- or 6-weeks post-hatching and were consistent with important growth of cuttlefish and essential roles of these elements, such as hemocyanin synthesis for $\mathrm{Cu}$, vitamin $\mathrm{B}_{12}$ production for $\mathrm{Co}$ and glutathion peroxidase activity for $\mathrm{Se}$.

The determination of positive correlations between soluble and insoluble concentrations revealed two distinct groups. The first group comprises $\mathrm{Ag}, \mathrm{Cd}, \mathrm{Co}, \mathrm{Cu}$ and $\mathrm{Zn}$, all of which are known to highly accumulate in the cephalopod digestive gland and to have affinity for sulfur-containing proteins such as MTs (Amiard et al., 2006; Vašák, 1991). In contrast, the second group is composed of trace elements that do not accumulate in the digestive gland: As, $\mathrm{Cr}, \mathrm{Mn}$ and $\mathrm{Ni}$ are homogeneously allocated in cephalopod tissues and $\mathrm{Fe}$ accumulates in other organs (Bustamante et al., 2008, 2000; Kojadinovic et al., 2011; Miramand and Bentley, 1992; Miramand and Guary, 1980; Napoleão et al., 2005; Raimundo et al., 2014, 2010; Schipp and Hevert, 1978; Ueda et al., 1979) (Tables 3 and 4). 
The only elements with soluble fraction positively correlated with MT concentrations in our study were $\mathrm{Cu}$ and $\mathrm{Zn}$, consistently with the major role of MTs in homeostasis of both elements (e.g. Amiard et al., 2006; Cosson, 1991; Roesijadi, 1992). These correlations are also consistent with the potential role of MTs in the detoxification process of non-essential metals such as Ag and Cd (Table 3).

\subsection{Zn exposures}

The $\mathrm{Zn}$ accumulation observed during our experiment highlighted the decreasing ability of juvenile cuttlefish to regulate the Zn-buildup when exposed to dissolved concentrations equal or above $52 \pm 3 \mu \mathrm{g} \mathrm{l}^{-1}$ (Z1; Fig. 2). Notably, this treshold appeared low considering $\mathrm{Zn}$ accumulation in other marine organisms such as the crustaceans Palaemon elegans and Carcinus maenas (Rainbow, 1985; White and Rainbow, 1982) and the bivalve Perna viridis (Chan, 1988) which regulated $\mathrm{Zn}$ buildup at concentrations above $100 \mu \mathrm{g} \mathrm{l^{-1 }}$. Nevertheless, metal uptake appears strongly species specific (e.g. Rainbow, 2002; Wang and Rainbow, 2005). The stabilization of $\mathrm{Zn}$ concentration occurring in $\mathrm{Z1}$ animals after 4-week exposure (around $302 \pm 27 \mu \mathrm{g} \mathrm{g}^{-1} \mathrm{dw}$ ) likely resulted from an equilibrium state between water and concentrations reached in animals rather than from a regulatory process (Fig. 2). Indeed, in $\mathrm{Z} 2$ conditions, $\mathrm{Zn}$ accumulation was observed at all time-points, whereas regulatory processes in other aquatic organisms lead to maintenance of internal concentrations close to control levels (Chan, 1988; Rainbow, 1985; White and Rainbow, 1982).

Apart from this $\mathrm{Zn}$ accumulation, a $\mathrm{Zn}$ dose-dependent depletion of total $\mathrm{Mn}$ in animals was observed during $\mathrm{Zn}$ exposures without fractionation or profile concentration changes (Fig. 3). To the best of our knowledge, such depletion of Mn concentrations due to $\mathrm{Zn}$ exposure was not previously reported. According to the similar chemical properties of $\mathrm{Mn}^{2+}$ and $\mathrm{Zn}^{2+}$ ions, Mn substitution by $\mathrm{Zn}$ appears likely: these elements are both used in 
enzymes as Lewis acids (Bock et al., 1999; McCall et al., 2000) and their divalent ions have almost the same radius (0.75 $\AA$ for $\mathrm{Mn}^{2+}$ and $0.74 \AA$ for $\mathrm{Zn}^{2+}$; Bock et al., 1999). In addition, $\mathrm{Mn}$ and $\mathrm{Zn}$ are borderline metals without binding preferences for oxygen, nitrogen and sulfure ligands, and as such are found in the two main types of metal rich granules in mollusks: those rich in phosphate salts, and those rich in sulfure salts (Chvapil, 1973; Marigómez et al., 2002; Niebœr and Richardson, 1980; Pan and Wang, 2012). Our study suggests Zn binding to Mn ligands at high dissolved $\mathrm{Zn}$ concentrations ( $\mathrm{Z} 1$ and above). Because such $\mathrm{Mn}^{2+}$ replacement is most often observed with $\mathrm{Mg}^{2+}, \mathrm{Mg}$ homeostasis could be an important parameter to survey under Zn perturbation (Bock et al., 1999).

The increase in soluble Ag-, $\mathrm{Cd}$ - and $\mathrm{Cu}$ fractions observed in $\mathrm{Zn}$-exposed juveniles (Fig. 4) differed from those found in similar studies on bivalves which reported some modifications in metal accumulation due to new ligand synthesis (e.g. MTs, GSH), thus allowing higher metal burden (e.g. Liu and Wang, 2014, 2013). In our study, no accumulation modifications were observed, except for $\mathrm{Zn}$, in spite of modified subcellular distributions, thus suggesting the absence of $\mathrm{Zn}$-induced synthesis of new ligand (Mouneyrac et al., 2002). We suggest that insoluble ligands of $\mathrm{Ag}, \mathrm{Cd}$, and $\mathrm{Cu}$ become occupied by significantly accumulated $\mathrm{Zn}$, resulting in the observed increase of their respective soluble fractions. Such increases would have to be regulated by soluble ligands such as MTs, GSH and/or high molecular weight proteins (HMWP) to avoid the production of ROS and their associated damages. According to the positive correlation found between MTs and $\mathrm{Zn}$ in control juveniles, the different biological half-life of MT depending of their cation linkage and the previously reported shorter half-life of Zn-thioneins, we also suggest that the lack of MTs increase in $\mathrm{Z} 1$ and their decrease in $\mathrm{Z} 2$ (Fig. 5) may result from their intensive use by $\mathrm{Zn}$ resulting on progressive depletion of the MTs cuttlefish stock (Amiard et al., 2006; Cosson, 1991). Alternatively, this decrease may result from important MT degradation after metal 
transport into lysosomes for metal rich granule formation (Liu and Wang, 2013; Mouneyrac et al., 2002). The management of $\mathrm{Ag}, \mathrm{Cd}, \mathrm{Cu}$ and $\mathrm{Zn}$ could also be assured by other cytosolic molecules such as the small tripeptide glutathion (GSH) which is one of the most abundant sulfure ligands found in most cells (Dickinson and Forman, 2002), and/or HMWP (Serafim and Bebianno, 2010). Consistently with this hypothesis, a study describing subcellular fractions of metals in the cuttlefish digestive gland highlighted that a part of cytosolic $\mathrm{Cd}, \mathrm{Cu}$ and $\mathrm{Zn}$ were linked with compounds of size range similar to GSH and HMWP, whereas cytosolic Ag was detected only associated with compounds of HMWP size range (Bustamante et al., 2006a).

Oxidative stress bioassays indicated a lack of gill sensitivity to $\mathrm{Zn}$ exposure, suggesting the absence of $\mathrm{Zn}$ accumulation in cephalopod gills, unlike previously reported in bivalves (Company et al., 2010, 2008; Funes et al., 2006). In contrast, all biomarkers were affected by $\mathrm{Zn}$ exposure in the digestive gland, highlighting increased oxidative stress and reduced regulation of ROS resulting from $\mathrm{Zn}$ accumulation. First, the increase in GST activity after 1 and 2 month-exposure to Z2 and Z1 (Fig. 6), respectively, was consistent with an increase in free metal binding as the GST enzyme conjugates GSH with a great variety of electrophilic compounds such as metal ions to avoid ROS production (Dickinson and Forman, 2002). A possible consequence of this elevated GST activity is the depletion in free GSH, further increasing free metal concentrations (Dickinson and Forman, 2002). Second, the SOD activity increase measured after 4-, 6- and 8-week exposure to Z1 highligthed an increased ROS production under the superoxide anion form $\left(\mathrm{O}_{2}^{-{ }^{-}}\right)$, which is consistent with a saturation of the metal-ligation system. SOD activity reduces $\mathrm{O}_{2}{ }^{--}-$the first synthetized oxygen freeradicals, into $\mathrm{H}_{2} \mathrm{O}_{2}$ (Halliwell and Gutteridget, 1984; Janknegt et al., 2007), which is then decomposed into $\mathrm{H}_{2} \mathrm{O}$ and $\mathrm{O}_{2}$ by catalase (Wang et al., 2013). The catalase activity decrease observed after 6- and 8-week exposure in Z1 contrasts with the increased SOD activity and 
suggests an imbalance in ROS management. This decreased catalase activity may result from previously described inhibitory effects of $\mathrm{Zn}, \mathrm{Cd}$ and/or $\mathrm{Cu}$ on this enzyme (Chandran et al., 2005; Company et al., 2004; Geret et al., 2002). The increase in LPO in Z1 after 6-week exposure confirmed such imbalance occuring simultaneously to catalase decrease (Fig. 7). Nevertheless, no effect was observed before this period, whereas increases in $\mathrm{Ag}-, \mathrm{Cd}-$ and $\mathrm{Zn}$ cytosolic concentrations were detected starting at 2 weeks of $\mathrm{Zn}$ exposure, or 4 weeks in the case of $\mathrm{Cu}$, suggesting a progressive decrease in the regulation of ROS production.

Our results highlighted the great sensitivity of juvenile cuttlefish to dissolved $\mathrm{Zn}$ exposure. For the first time in a cephalopod, modification of metal concentrations as well as subcellular distributions by a single metal exposure is highlighted. According to these perturbations, our results suggest a low plasticity of this stage of life to regulate the effects of medium dissolved $\mathrm{Zn}$ exposure such as oxidative stress. The synthesis of new ligands to control accumulation of this element appeared very limited. Moreover, we studied the ability to control the ROS production in several tissues in a juvenile cephalopod. Contrarily to those of bivalves, cuttlefish gills presented a lower $\mathrm{Zn}$ accumulation potential compare to digestive gland. In this tissue, damages were recorded after 6-week exposure in $52 \mu \mathrm{g}^{-1}-\mathrm{a}$ concentration lower or of the same order than values registered in coastal environments (Lachambre and Fisson, 2007a; Sheahan et al., 2007) and gulfs or estuaries (Amado Filho et al., 1997; Di Salvatore et al., 2013; Liu and Wang, 2013; Popham and D'Auria, 1982; Srinivasa Reddy et al., 2005), worldwide. Further studies on other pollutants will be necessary to characterize the breadth of cuttlefish sensitivity to anthropogenic contamination and confirm its impact on cuttlefish recruitment, as previously suggested by Gras (2013).

\section{Acknowledgments}


This work was supported by the European, Interreg IV-A CHRONEXPO project. This study was partly conducted in the CREC (Centre de Recherche en Environnement Côtier) at Luc-sur-mer (Normandie, France). The authors thank Dr Pierre Le Pabic for advice and help in English, and C. Churlaud and M. Brault-Favrou from the Plateforme "Analyses Elémentaires" of the LIENSs laboratory for their assistance in trace element analyses. The CPER is aknowledge for funding the analytical devices.

\section{References}

Amado Filho, G.M., Karez, C.S., Andrade, L.R., Yoneshigue-Valentin, Y., Pfeiffer, W.C., 1997. Effects on growth and accumulation of zinc in six seaweed species. Ecotoxicol. Environ. Saf. 37, 223-8.

Amiard, J.-C., Amiard-Triquet, C., Barka, S., Pellerin, J., Rainbow, P.S., 2006. Metallothioneins in aquatic invertebrates: their role in metal detoxification and their use as biomarkers. Aquat. Toxicol. 76, 160-202.

Ansari, Z.A., Desilva, C., Badesab, S., 2012. Total petroleum hydrocarbon in the tissues of some commercially important fishes of the Bay of Bengal. Mar. Pollut. Bull. 64, 2564-8.

Babo, S., Vasseur, P., 1992. In vitro effects of Thiram on liver antioxidant enzyme activities of rainbow trout (Oncorhynchus mykiss). Aquat. Toxicol. 22, 61-68.

Blackmore, G., Wang, W.-X., 2002. Uptake and efflux of $\mathrm{Cd}$ and $\mathrm{Zn}$ by the green mussel Perna viridis after metal preexposure. Environ. Sci. \& Technol. 36, 989-95.

Bloor, I.S.M., Attrill, M.J., Jackson, E.L., 2013. A review of the factors influencing spawning, early life stage survival and recruitment variability in the common cuttlefish (Sepia officinalis). Adv. Mar. Biol. 65, 1-65.

Bock, C.W., Katz, A.K., Markham, G.D., Glusker, J.P., 1999. Manganese as a replacement for magnesium and zinc: functional comparison of the divalent ions. J. Am. Chem. Soc. $121,7360-7372$.

Boucaud-Camou, E., Boismery, J., 1991. The migrations of the cuttlefish (Sepia officinalis L.) in the English Channel, in: Boucaud-Camou, E. (Ed.), La Seiche / The Cuttlefish. Centre de publication de l'Université de Caen, Caen, France, pp. 179-189.

Boust, D., Fischer, J.-C., Ouddane, B., Petit, F., Wartel, M., 2004. Fer et manganèse: réactivités et recyclages. 
Bradford, M.M., 1976. A rapid and sensitive method for the quantitation of microgram quantities of protein utilizing the principle of protein-dye binding. Anal. Biochem. 72, $248-254$.

Brereton, A., Lord, H., Thornton, I., Webb, J.S., 1973. Effect of zinc on growth and development of larvae of the Pacific oyster Crassostrea gigas. Mar. Biol. 19, 96-101.

Bustamante, P., Bertrand, M., Boucaud-Camou, E., Miramand, P., 2006a. Subcellular distribution of $\mathrm{Ag}, \mathrm{Cd}, \mathrm{Co}, \mathrm{Cu}, \mathrm{Fe}, \mathrm{Mn}, \mathrm{Pb}$, and $\mathrm{Zn}$ in the digestive gland of the common cuttlefish Sepia officinalis. J. Shellfish Res. 25, 987-993.

Bustamante, P., Caurant, F., Fowler, S.W., Miramand, P., 1998. Cephalopods as a vector for the transfer of cadmium to top marine predators in the north-east Atlantic Ocean. Sci. Total Environ. 220, 71-80.

Bustamante, P., Caurant, F., Fowler, S.W., Miramand, P., 1998. Cephalopods as a vector for the transfer of cadmium to top marine predators in the north-east Atlantic Ocean. Sci. Total Environ. 220, 71-80.

Bustamante, P., Cosson, R.P., Gallien, I., Caurant, F., Miramand, P., 2002a. Cadmium detoxification processes in the digestive gland of cephalopods in relation to accumulated cadmium concentrations. Mar. Environ. Res. 53, 227-241.

Bustamante, P., González, A.F., Rocha, F., Miramand, P., Guerra, Á., 2008. Metal and metalloid concentrations in the giant squid Architeuthis dux from Iberian waters. Mar. Environ. Res. 66, 278-287.

Bustamante, P., Grigioni, S., Boucher-Rodoni, R., Caurant, F., Miramand, P., 2000. Bioaccumulation of 12 trace elements in the tissues of the Nautilus Nautilus macromphalus from New Caledonia. Mar. Pollut. Bull. 40, 688-696.

Bustamante, P., Lahaye, V., Durnez, C., Churlaud, C., Caurant, F., 2006b. Total and organic $\mathrm{Hg}$ concentrations in cephalopods from the North Eastern Atlantic waters: influence of geographical origin and feeding ecology. Sci. Total Environ. 368, 585-96.

Bustamante, P., Teyssié, J.-L., Danis, B., Fowler, S.W., Miramand, P., Cotret, O., Warnau, M., 2004. Uptake, transfer and distribution of silver and cobalt in tissues of the common cuttlefish Sepia officinalis at different stages of its life cycle. Mar. Ecol. Prog. Ser. 269, $185-195$.

Bustamante, P., Teyssié, J.-L., Fowler, S., Cotret, O., Danis, B., Miramand, P., Warnau, M., 2002b. Biokinetics of cadmium and zinc accumulation and depuration at different stages in the life cycle of the cuttlefish Sepia officinalis. Mar. Ecol. Prog. Ser. 231, 167-177.

Bustamante, P., Teyssié, J.-L., Fowler, S.W., Warnau, M., 2006c. Assessment of the exposure pathway in the uptake and distribution of americium and cesium in cuttlefish (Sepia officinalis) at different stages of its life cycle. J. Exp. Mar. Bio. Ecol. 331, 198-207.

Chan, H.M., 1988. Accumulation and tolerance to cadmium, copper, lead and zinc by the green mussel Perna viridis. Mar. Ecol. Prog. Ser. 48, 295-303. 
Chandran, R., Sivakumar, A.A., Mohandass, S., Aruchami, M., 2005. Effect of cadmium and zinc on antioxidant enzyme activity in the gastropod, Achatina fulica. Comp. Biochem. Physiol. Toxicol. \& Pharmacol. 140, 422-6.

Chiffoleau, J.-F., Claisse, D., Cossa, D., Ficht, A., Gonzalez, J.-L., Guyot, T., Michel, P., Miramand, P., Oger, C., Petit, F., 2001. La contamination métallique.

Chouvelon, T., Spitz, J., Cherel, Y., Caurant, F., Sirmel, R., Mèndez-Fernandez, P., Bustamante, P., 2011. Inter-specific and ontogenic differences in $\delta^{13} \mathrm{C}$ and $\delta^{15} \mathrm{~N}$ values and $\mathrm{Hg}$ and $\mathrm{Cd}$ concentrations in cephalopods. Mar. Ecol. Prog. Ser. 433, 107-120.

Chvapil, M., 1973. New aspects in the biological role of zinc: a stabilizer of macromolecules and biological membranes. Life Sci. 13, 1041-1049.

Clarke, M.R., 1996. Cephalopods as prey. III. Cetaceans. Philos. Trans. R. Soc. B Biol. Sci. 351, 1053-1065.

Colas, S., 2011. Pollutions et qualité du milieu marin, Environnement littoral et marin. Nancy, France.

Company, R., Serafim, A., Bebianno, M.J., Cosson, R.P., Shillito, B., Fiala-Médioni, A., 2004. Effect of cadmium, copper and mercury on antioxidant enzyme activities and lipid peroxidation in the gills of the hydrothermal vent mussel Bathymodiolus azoricus. Mar. Environ. Res. 58, 377-81.

Company, R., Serafim, A., Cosson, R.P., Fiala-Médioni, A., Camus, L., Colaço, A., SerrãoSantos, R., Bebianno, M.J., 2008. Antioxidant biochemical responses to long-term copper exposure in Bathymodiolus azoricus from Menez-Gwen hydrothermal vent. Sci. Total Environ. 389, 407-17.

Company, R., Serafim, A., Cosson, R.P., Fiala-Médioni, A., Camus, L., Serrão-Santos, R., João Bebianno, M., 2010. Sub-lethal effects of cadmium on the antioxidant defence system of the hydrothermal vent mussel Bathymodiolus azoricus. Ecotoxicol. Environ. Saf. 73, 788-95.

Cosson, R.P., 1991. Metallothioneins and detoxification. Is the use of detoxification protein for MTs a language abuse? Water, Air Soil Pollut. 555-567.

Craig, S., Overnell, J., 2003. Metals in squid, Loligo forbesi, adults, eggs and hatchlings. No evidence for a role for $\mathrm{Cu}$ - or $\mathrm{Zn}$-metallothionein. Comp. Biochem. Physiol. C. Toxicol. Pharmacol. 134, 311-7.

Danis, B., Bustamante, P., Cotret, O., Teyssie, J.-L., Fowler, S.W., Warnau, M., 2005. Bioaccumulation of PCBs in the cuttlefish Sepia officinalis from seawater, sediment and food pathways. Environ. Pollut. 134, 113-22.

Decleir, W., Vlaeminck, A., Geladi, P., Van Grieken, R., 1978. Determination of proteinbound copper and zinc in some organs of the cuttlefish Sepia officinalis L. Comp. Biochem. Physiol. 60B, 347-350. 
Devos, A., Voiseux, C., Caplat, C., Fievet, B., 2012. Effect of chronic exposure to zinc in young spats of the Pacific oyster (Crassostrea gigas). Environ. Toxicol. Chem. 31, 2841-7.

Di Poi, C., Bidel, F., Dickel, L., Bellanger, C., 2014. Cryptic and biochemical responses of young cuttlefish Sepia officinalis exposed to environmentally relevant concentrations of fluoxetine. Aquat. Toxicol.

Di Poi, C., Darmaillacq, A.-S., Dickel, L., Boulouard, M., Bellanger, C., 2013. Effects of perinatal exposure to waterborne fluoxetine on memory processing in the cuttlefish Sepia officinalis. Aquat. Toxicol. 132-133, 84-91.

Di Salvatore, P., Calcagno, J.A., Ortíz, N., Ríos de Molina, M.D.C., Sabatini, S.E., 2013. Effect of seasonality on oxidative stress responses and metal accumulation in soft tissues of Aulacomya atra, a mussel from the South Atlantic Patagonian coast. Mar. Environ. Res. 92, 244-52.

Dickinson, D.A., Forman, H.J., 2002. Cellular glutathione and thiols metabolism. Biochem. Pharmacol. 64, 1019-26.

Etourneau, C., Françoise, S., Lamort, L., Mary, C., Parrad, S., Normand, J., Menet-Nédelec, F., 2013. Bulletin de la Surveillance de la Qualité du Milieu Marin Littoral 2012 Départements: Seine Maritime, Eure, Calvados, Manche.

Finger, J.M., Smith, J.D., 1987. Molecular association of $\mathrm{Cu}, \mathrm{Zn}, \mathrm{Cd}$ and ${ }^{210} \mathrm{Po}$ in the digestive gland of the squid Nototodarus gouldi. Mar. Biol. 95, 87-91.

Forsythe, J.W., DeRusha, R.H., Hanlon, R.T., 1994. Growth, reproduction and life span of Sepia officinalis (Cephalopoda: Mollusca) cultured through seven consecutive generations. J. Zool. London 233, 175-192.

Fox, J., Weisberg, S., 2011. An $\{\mathrm{R}\}$ companion to applied regression, second edition. Thousand Oaks CA: Sage. http://socserv.socsci.mcmaster.ca/jfox/Books/Companion

Funes, V., Alhama, J., Navas, J.I., López-Barea, J., Peinado, J., 2006. Ecotoxicological effects of metal pollution in two mollusc species from the Spanish South Atlantic littoral. Environ. Pollut. 139, 214-23.

Gérard-Monnier, D., Erdelmeier, I., Régnard, K., Moze-Henry, N., Yadan, J.-C., Chaudière, J., 1998. Reactions of 1-methyl-2-phenylindole with malondialdehyde and 4hydroxyalkenals. Analytical applications to a colorimetric assay of lipid peroxidation. Chem. Res. Toxicol. 11, 1176-83.

Geret, F., Cosson, R.P., 2002. Induction of specific isoforms of metallothionein in mussel tissues after exposure to cadmium or mercury. Arch. Environ. Contam. Toxicol. 42, 3642.

Geret, F., Serafim, A., Barreira, L., Bebianno, M.J., 2002. Response of antioxidant systems to copper in the gills of the clam Ruditapes decussatus. Mar. Environ. Res. 54, 413-7. 
Gras, M., 2013. Contribution des frayères côtières au recrutement du stock de seiche Sepia officinalis de Manche: lien entre le succès de la phase pré-recrutée et l'abondance de la ressource. Université de Caen Basse-Normandie.

Habig, W.H., Pabst, M.J., Jakoby, W.B., 1974. Glutathione S-Transferases, the first enzymatic steps in mercapturic acid formation. J. Biol. Chem. 249, 7130-7139.

Halliwell, B., Gutteridget, J.M.C., 1984. Oxygen toxicity, oxygen radicals, transition metals and disease. Biochem. J. 219, 1-14.

Hennig, H.F., 1986. Metal-binding proteins as metal pollution indicators. Environ. Health Perspect. 65, 175-87.

Hervé, M., 2012. RVAideMemoire: Diverse basic statistical and graphical functions. R package version 0.9-11. http://CRAN.R-project.org/package=RVAideMemoire

Horowitz, A., Presley, B.J., 1977. Trace metal concentrations and partitioning in zooplankton, neuston, and benthos from the south Texas outer continental shelf. Arch. Environ. Contam. Toxicol. 5, 241-255.

Ichihashi, H., Kohno, H., Kannan, K., Tsumura, A., Yamasaki, S.-I., 2001a. Multielemental analysis of purpleback flying squid using high resolution inductively coupled plasmamass spectrometry (HR ICP-MS). Environ. Sci. \& Technol. 35, 3103-3108.

Ichihashi, H., Nakamura, Y., Kannan, K., Tsumura, A., Yamasaki, S., 2001b. Multi-elemental concentrations in tissues of Japanese common squid (Todarodes pacificus). Arch. Environ. Contam. Toxicol. 41, 483-90.

Ifremer, 2007. Les contaminants chimiques dans les huîtres et les moules du littoral français [WWW Document]. Résultats du réseau Surveill. ROCCH (ex RNO) pour la période 2003-2007.

URL http://envlit.ifremer.fr/var/envlit/storage/documents/parammaps/contaminantschimiques/ (accessed 4.8.14).

Janknegt, P.J., Rijstenbil, J.W., van de Poll, W.H., Gechev, T.S., Buma, A.G.J., 2007. A comparison of quantitative and qualitative superoxide dismutase assays for application to low temperature microalgae. J. Photochem. Photobiol. B Biol. 87, 218-26.

Jereb, P., Roper, C.F.E., Vecchione, M., 2005. Introduction, in: Jereb, P., Roper, C.F.E. (Eds.), Cephalopods of the World. An Annotated and Illustrated Catalogue of Species Known to Date. Volume 1. Chambered Nautiluses and Sepioids (Nautilidae, Sepiidae, Sepiolidae, Sepiadariidae, Idiospiidae and Spirulidae). Rome, pp. 1-19.

Kojadinovic, J., Jackson, C.H., Cherel, Y., Jackson, G.D., Bustamante, P., 2011. Multielemental concentrations in the tissues of the oceanic squid Todarodes filippovae from Tasmania and the southern Indian Ocean. Ecotoxicol. Environ. Saf. 74, 1238-49.

Lachambre, M., Fisson, C., 2007a. La contamination chimique: quel risque en estuaire de Seine - Fiche substance: Zinc. 
Lachambre, M., Fisson, C., 2007b. La contamination chimique: quel risque en estuaire de Seine - Fiche substance: Argent.

Lachambre, M., Fisson, C., 2007c. La contamination chimique: quel risque en estuaire de Seine - Fiche substance: Arsenic.

Lacoue-Labarthe, T., Bustamante, P., Hörlin, E., Luna-Acosta, A., Bado-Nilles, A., ThomasGuyon, H., 2009a. Phenoloxidase activation in the embryo of the common cuttlefish Sepia officinalis and responses to the $\mathrm{Ag}$ and $\mathrm{Cu}$ exposure. Fish \& Shellfish Immunol. 27, 516-521.

Lacoue-Labarthe, T., Le Bihan, E., Borg, D., Koueta, N., Bustamante, P., 2010a. Acid phosphatase and cathepsin activity in cuttlefish (Sepia officinalis) eggs: the effects of $\mathrm{Ag}, \mathrm{Cd}$, and $\mathrm{Cu}$ exposure. ICES J. Mar. Sci. 67, 1517-1523.

Lacoue-Labarthe, T., Villanueva, R., Rouleau, C., Oberhänsli, F., Teyssié, J.-L., Jeffree, R., Bustamante, P., 2011. Radioisotopes demonstrate the contrasting bioaccumulation capacities of heavy metals in embryonic stages of cephalopod species. PLoS One 6, e27653.

Lacoue-Labarthe, T., Warnau, M., Metian, M., Oberhänsli, F., Rouleau, C., Bustamante, P., 2009b. Biokinetics of $\mathrm{Hg}$ and $\mathrm{Pb}$ accumulation in the encapsulated egg of the common cuttlefish Sepia officinalis: radiotracer experiments. Sci. Total Environ. 407, 6188-6195.

Lacoue-Labarthe, T., Warnau, M., Oberhänsli, F., Teyssié, J.-L., Bustamante, P., 2009c. Bioaccumulation of inorganic $\mathrm{Hg}$ by the juvenile cuttlefish Sepia officinalis exposed to ${ }^{203} \mathrm{Hg}$ radiolabelled seawater and food. Aquat. Biol. 6, 91-98.

Lacoue-Labarthe, T., Warnau, M., Oberhänsli, F., Teyssié, J.-L., Bustamante, P., 2010b. Contrasting accumulation biokinetics and distribution of ${ }^{241} \mathrm{Am}, \mathrm{Co}, \mathrm{Cs}, \mathrm{Mn}$ and $\mathrm{Zn}$ during the whole development time of the eggs of the common cuttlefish, Sepia officinalis. J. Exp. Mar. Bio. Ecol. 382, 131-138.

Lacoue-Labarthe, T., Warnau, M., Oberhänsli, F., Teyssie, J.-L., Jeffree, R., Bustamante, P., 2008a. First experiments on the maternal transfer of metals in the cuttlefish Sepia officinalis. Mar. Pollut. Bull. 57, 826-831.

Lacoue-Labarthe, T., Warnau, M., Oberhänsli, F., Teyssie, J.-L., Koueta, N., Bustamante, P., 2008b. Differential bioaccumulation behaviour of $\mathrm{Ag}$ and $\mathrm{Cd}$ during the early development of the cuttlefish Sepia officinalis. Aquat. Toxicol. 86, 437-446.

Le Goff, R., Daguzan, J., 1991. Growth and life cycles of the cuttlefish Sepia officinalis L. (Mollusca: Cephalopoda) in South Brittany (France). Bull. Mar. Sci. 49, 341-348.

Lemoine, S., Bigot, Y., Sellos, D., Cosson, R.P., Laulier, M., 2000. Metallothionein isoforms in Mytilus edulis (Mollusca, Bivalvia): complementary DNA characterization and quantification of expression in different organs after exposure to cadmium, zinc, and copper. Mar. Biotechnol. 2, 195-203. 
Le Pabic, C., Caplat, C., Lehodey, J.-P., Dallas, L., Koueta, N. under review. Physiological perturbations in juvenile cuttlefish Sepia officinalis induced by subchronic exposure to dissolved zinc. Mar. Pollut. Bull.

Liu, F., Wang, W.-X., 2013. Facilitated bioaccumulation of cadmium and copper in the oyster Crassostrea hongkongensis solely exposed to zinc. Environ. Sci. \& Technol. 47, 1670-7.

Liu, F., Wang, W.-X., 2014. Differential influences of $\mathrm{Cu}$ and $\mathrm{Zn}$ chronic exposure on $\mathrm{Cd}$ and $\mathrm{Hg}$ bioaccumulation in an estuarine oyster. Aquat. Toxicol. 148, 204-10.

Lucia, M., Bocher, P., Cosson, R.P., Churlaud, C., Robin, F., Bustamante, P., 2012. Insight on trace element detoxification in the Black-tailed Godwit (Limosa limosa) through genetic, enzymatic and metallothionein analyses. Sci. Total Environ. 423, 73-83.

Malanga, G., Estevez, M.S., Calvo, J., Puntarulo, S., 2004. Oxidative stress in limpets exposed to different environmental conditions in the Beagle Channel. Aquat. Toxicol. 69, 299-309.

Marigómez, I., Soto, M., Cajaraville, M.P., Angulo, E., Giamberini, L., 2002. Cellular and subcellular distribution of metals in molluscs. Microsc. Res. Tech. 56, 358-92.

Martin, J.H., Flegal, A.R., 1975. High copper concentrations in squid livers in association with elevated levels of silver, cadmium, and zinc. Mar. Biol. 30, 51-55.

Martoja, M., Marcaillou, C., 1993. Localisation cytologique du cuivre et de quelques autres métaux dans la glande digestive de la seiche, Sepia officinalis L. (Mollusque Céphalopode). Can. J. Fish. Aquat. Sci. 50, 542-550.

McCall, K.A., Huang, C., Fierke, C.A., 2000. Function and mechanism of zinc metalloenzymes. J. Nutr. 130, 1437S-1446S.

Metian, M., Bustamante, P., Hédouin, L., Warnau, M., 2008. Accumulation of nine metals and one metalloid in the tropical scallop Comptopallium radula from coral reefs in New Caledonia. Environ. Pollut. 152, 543-552.

Miramand, P., Bentley, D., 1992. Concentration and distribution of heavy metals in tissues of two cephalopods, Eledone cirrhosa and Sepia officinalis, from the French coast of the English Channel. Mar. Biol. 114, 407-414.

Miramand, P., Bustamante, P., Bentley, D., Koueta, N., 2006. Variation of heavy metal concentrations ( $\mathrm{Ag}, \mathrm{Cd}, \mathrm{Co}, \mathrm{Cu}, \mathrm{Fe}, \mathrm{Pb}, \mathrm{V}$, and $\mathrm{Zn}$ ) during the life cycle of the common cuttlefish Sepia officinalis. Sci. Total Environ. 361, 132-143.

Miramand, P., Guary, J.C., 1980. High concentrations of some heavy metals in tissues of the Mediterranean Octopus. Bull. Environ. Contam. Toxicol. 24, 783-788.

Mouneyrac, C., Amiard, J.-C., Amiard-Triquet, C., Cottier, A., Rainbow, P.S., Smith, B.D., 2002. Partitioning of accumulated trace metals in the talitrid amphipod crustacean Orchestia gammarellus: a cautionary tale on the use of metallothionein-like proteins as biomarkers. Aquat. Toxicol. 57, 225-42. 
Nadella, S.R., Tellis, M.S., Diamond, R., Smith, S., Bianchini, A., Wood, C.M., 2013. Toxicity of lead and zinc to developing mussel and sea urchin embryos: critical tissue residues and effects of dissolved organic matter and salinity. Comp. Biochem. Physiol. Toxicol. \& Pharmacol. 158, 72-83.

Napoleão, P., Pinheiro, T., Sousa Reis, C., 2005. Elemental characterization of tissues of Octopus vulgaris along the Portuguese coast. Sci. Total Environ. 345, 41-9.

Niebœr, E., Richardson, D.H.S., 1980. The replacement of the nondescript term "heavy metals" by a biologically and chemically significant classification of metal ions. Environ. Pollut. 1, 3-26.

Oestmann, D.J., Scimeca, J.M., Forsythe, J., Hanlon, R.T., Lee, P., 1997. Special considerations for keeping cephalopods in laboratory facilities. J. Am. Assoc. Lab. Anim. Sci. 36, 89-93.

Pan, K., Wang, W.-X., 2012. Reconstructing the biokinetic processes of oysters to counteract the metal challenges: physiological acclimation. Environ. Sci. \& Technol. 46, 10765-71.

Paoletti, F., Aldinucci, D., Mocali, A., Caparrini, A., 1986. A sensitive spectrophotometric method for the determination of superoxide dismutase activity in tissue extracts. Anal. Biochem. 154, 536-541.

Pierce, G.J., Allcock, L., Bruno, I., Bustamante, P., González, Á., Guerra, Á., Jereb, P., Lefkaditou, E., Malham, S.K., Moreno, A., Pereira, J., Piatkowski, U., Rasero, M., Sánchez, P., Santos, M.B., Santurtún, M., Seixas, S., Sobrino, I., Villanueva, R., 2010. Cephalopod biology and fisheries in Europe (No. 303). Copenhagen.

Pierce, G.J., Valavanis, V.D., Guerra, Á., Jereb, P., Orsi-Relini, L., Bellido, J.M., Katara, I., Piatkowski, U., Pereira, J., Balguerias, E., Sobrino, I., Lefkaditou, E., Wang, J., Santurtún, M., Boyle, P.R., Hastie, L.C., MacLeod, C.D., Smith, J.M., Viana, M., González, A.F., Zuur, A.F., 2008. A review of cephalopod - environment interactions in European Seas. Hydrobiologia 612, 49-70.

Popham, J.D., D'Auria, J.M., 1982. Effects of season and seawater concentrations on trace metal concentrations in organs of Mytilus edulis. Arch. Environ. Contam. Toxicol. 11, 273-82.

Radwan, M.A., El-Gendy, K.S., Gad, A.F., 2010. Oxidative stress biomarkers in the digestive gland of Theba pisana exposed to heavy metals. Arch. Environ. Contam. Toxicol. 58, 828-35.

Raimundo, J., Costa, P.M., Vale, C., Costa, M.H., Moura, I., 2010. Metallothioneins and trace elements in digestive gland, gills, kidney and gonads of Octopus vulgaris. Comp. Biochem. Physiol. Toxicol. \& Pharmacol. 152, 139-146.

Raimundo, J., Vale, C., Rosa, R., 2014. Trace element concentrations in the top predator jumbo squid (Dosidicus gigas) from the Gulf of California. Ecotoxicol. Environ. Saf. 102C, 179-186. 
Rainbow, P.S., 1985. Accumulation of $\mathrm{Zn}, \mathrm{Cu}$ and $\mathrm{Cd}$ by crabs and barnacles. Estuar. Coast. Shelf Sci. 21, 669-686.

Rainbow, P.S., 2002. Trace metal concentrations in aquatic invertebrates: why and so what? Environ. Pollut. 120, 497-507.

Rainbow, P.S., White, S.L., 1989. Comparative strategies of heavy metal accumulation by crustaceans: zinc, copper and cadmium in a decapod, an amphipod and a barnacle. Hydrobiologia 174, 245-262.

R Core Team, 2012. R: A language and environment for statistical computing. R Foundation for Statistical Computing, Vienna, Austria. ISBN 3-900051-07-0, URL http://www.Rproject.org/.

Regoli, F., Principato, G., 1995. Glutathone, glutathione-dependent and antioxidant enzymes in mussel, Mytilus galloprovincialis, exposed to metals under field and laboratory conditions: implications for the use of biochemical biomarkers. Aquat. Toxicol. 31, 143164.

Rjeibi, M., Metian, M., Hajji, T., Guyot, T., Ben Chaouacha-Chékir, R., Bustamante, P., 2014. Interspecific and geographical variations of trace metal concentrations in cephalopods from Tunisian waters. Environ. Monit. Assess. 186, 3767-83.

Roesijadi, G., 1992. Metallothioneins in metal regulation and toxicity in aquatic aimals. Aquat. Toxicol. 22, 81-114.

Schipp, R., Hevert, F., 1978. Distribution of copper and iron in some central organs of Sepia officinalis (Cephalopoda). A comparative study by flameless atomic absorption and electron microscopy. Mar. Biol. 47, 391-399.

Semedo, M., Reis-Henriques, M.A., Rey-Salgueiro, L., Oliveira, M., Delerue-Matos, C., Morais, S., Ferreira, M., 2012. Metal accumulation and oxidative stress biomarkers in octopus (Octopus vulgaris) from Northwest Atlantic. Sci. Total Environ. 433, 230-237.

Sen, H., Sunlu, U., 2007. Effects of Cadmium $\left(\mathrm{CdCl}_{2}\right)$ on development and hatching of eggs in European squid (Loligo vulgaris Lamarck, 1798) (Cephalopoda: Loliginidae). Environ. Monit. Assess. 133, 371-8.

Serafim, A., Bebianno, M.J., 2010. Effect of a polymetallic mixture on metal accumulation and metallothionein response in the clam Ruditapes decussatus. Aquat. Toxicol. 99, $370-8$.

Sheahan, D., Brooks, S., Raffo, A., Smedley, C., Law, R., 2007. A Review of the Contaminant Status of SEA 8 covering the Western Approaches, Celtic Sea and English Channel (No. C3006).

Shi, D., Wang, W.-X., 2004. Understanding the differences in $\mathrm{Cd}$ and $\mathrm{Zn}$ bioaccumulation and subcellular storage among different populations of marine clams. Environ. Sci. \& Technol. 38, 449-56. 
Srinivasa Reddy, M., Basha, S., Joshi, H. V, Ramachandraiah, G., 2005. Seasonal distribution and contamination levels of total PHCs, PAHs and heavy metals in coastal waters of the Alang-Sosiya ship scrapping yard, Gulf of Cambay, India. Chemosphere 61, 1587-93.

Tanaka, T., Hayashi, Y., Ishizawa, M., 1983. Subcellulardistribution and binding of heavy metals in the untreated liver of the squid; comparison with data from the livers of cadmium and silver-exposed rats. Experientia 39, 746-748.

Tellis, M.S., Lauer, M.M., Nadella, S.R., Bianchini, A., Wood, C.M., 2014. Sublethal mechanisms of $\mathrm{Pb}$ and $\mathrm{Zn}$ toxicity to the purple sea urchin (Strongylocentrotus purpuratus) during early development. Aquat. Toxicol. 146, 220-9.

Ueda, T., Nakahara, M., Ishii, T., Suzuki, Y., Suzuki, H., 1979. Amounts of trace elements in marine cephalopods. J. Radiat. Res. 20, 338-342.

Vašák, M., 1991. Metal removal and substitution in vertebrate and invertebrate metallothioneins. Methods Enzymol. 205, 452-458.

Villanueva, R., Bustamante, P., 2006. Composition in essential and non-essential elements of early stages of cephalopods and dietary effects on the elemental profiles of Octopus vulgaris paralarvae. Aquaculture 261, 225-240.

Vlahogianni, T., Dassenakis, M., Scoullos, M.J., Valavanidis, A., 2007. Integrated use of biomarkers (superoxide dismutase, catalase and lipid peroxidation) in mussels Mytilus galloprovincialis for assessing heavy metals' pollution in coastal areas from the Saronikos Gulf of Greece. Mar. Pollut. Bull. 54, 1361-71.

Wallace, W., Lee, B., Luoma, S., 2003. Subcellular compartmentalization of Cd and Zn in two bivalves. I. Significance of metal-sensitive fractions (MSF) and biologically detoxified metal (BDM). Mar. Ecol. Prog. Ser. 249, 183-197.

Wang, C., Yue, X., Lu, X., Liu, B., 2013. The role of catalase in the immune response to oxidative stress and pathogen challenge in the clam Meretrix meretrix. Fish \& Shellfish Immunol. 34, 91-9.

Wang, W.-X., Rainbow, P.S., 2005. Influence of metal exposure history on trace metal uptake and accumulation by marine invertebrates. Ecotoxicol. Environ. Saf. 61, 145-59.

Wang, W.-X., Rainbow, P.S., 2010. Significance of metallothioneins in metal accumulation kinetics in marine animals. Comp. Biochem. Physiol. Toxicol. \& Pharmacol. 152, 1-8.

Watling, H.R., 1982. Comparative study of the effects of zinc, cadmium, and copper on the larval growth of three oyster species. Bull. Environ. Contam. Toxicol. 28, 195-201.

White, S.L., Rainbow, P.S., 1982. Regulation and accumulation of copper, zinc and cadmium by the shrimp Palaemon elegans. Mar. Ecol. Prog. Ser. 8, 95-101.

Yim, M., Boucaud-Camou, E., 1980. Etude cytologique du développement post-embryonnaire de la glande digestive de Sepia officinalis L. (Mollusque Céphalopode). Arch. Anat. Microsc. Morphol. Exp. 69, 59-79. 
Zielinski, S., Pörtner, H.-O., 2000. Oxidative stress and antioxidative defense in cephalopods: a function of metabolic rate or age? Comp. Biochem. Physiol. Part B Biochem. \& Mol. Biol. 125, 147-160. 
Table 1: Trace element concentrations (mean $\pm \mathrm{SD} ; \mu \mathrm{g} \mathrm{g}{ }^{-1} \mathrm{dw}$ ) in whole juvenile Sepia officinalis during its two first months of life.

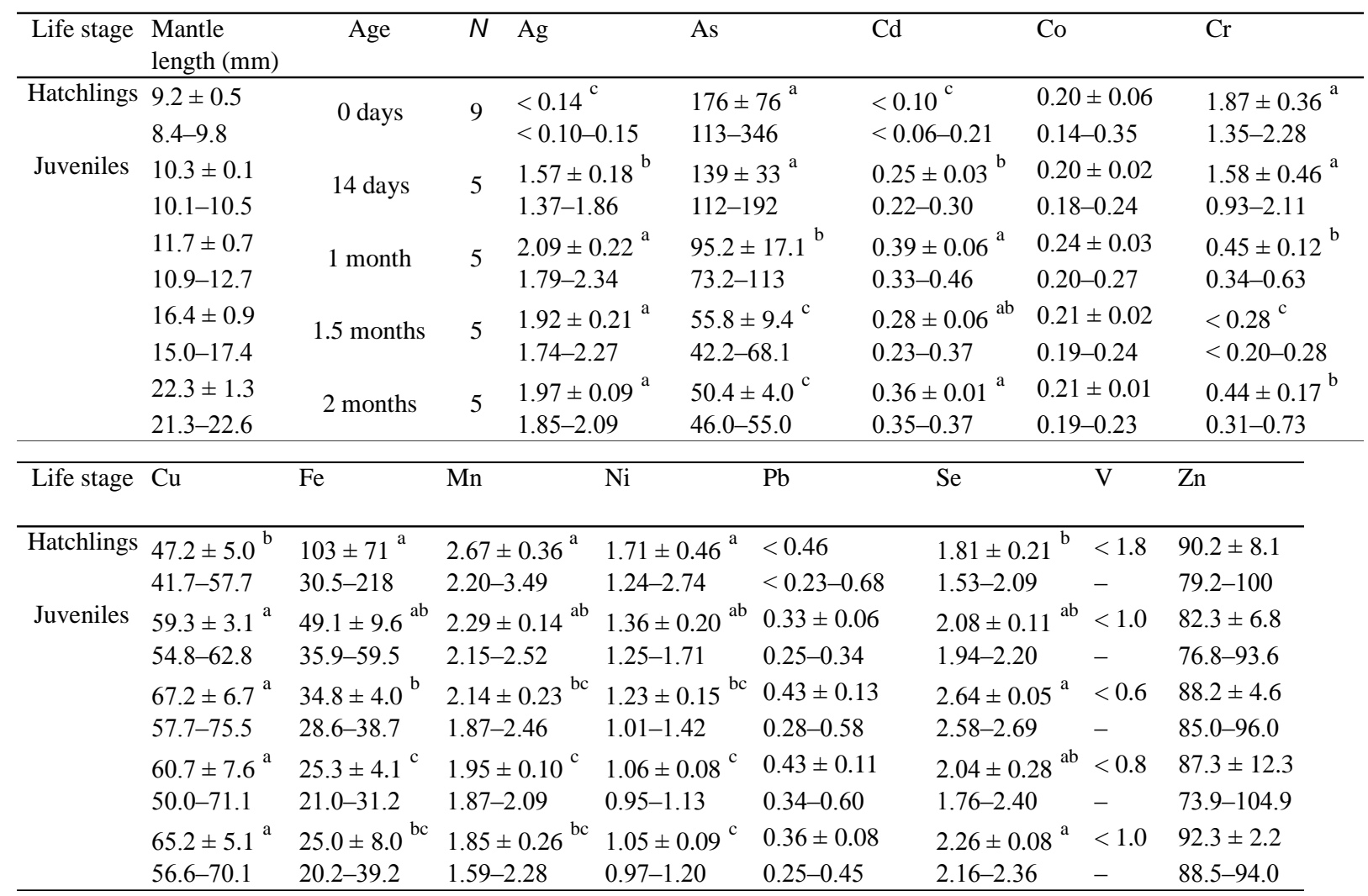

The different letters denote for each trace element, statistically significant differences (at $p$-value < $0.05)$ between sampling times $(\mathrm{a} \neq \mathrm{b} \neq \mathrm{c})$. 
Table 2: Soluble trace element proportion (mean $\pm \mathrm{SD} ; \%$ ) in whole juvenile Sepia officinalis during its two first months of life.

\begin{tabular}{|c|c|c|c|c|c|c|c|c|c|c|}
\hline Life stage & $\begin{array}{l}\text { Mantle } \\
\text { length }(\mathrm{mm})\end{array}$ & Age & $N$ & \multicolumn{2}{|l|}{$\mathrm{Ag}$} & \multicolumn{2}{|c|}{ As } & $\overline{\mathrm{Cd}}$ & Co & $\mathrm{Cr}$ \\
\hline Hatchlings & $\begin{array}{l}9.2 \pm 0.5 \\
8.4-9.8\end{array}$ & 0 days & 9 & \multicolumn{2}{|l|}{$\begin{array}{l}\text { n.d. } \\
\text { n.d. }\end{array}$} & \multicolumn{2}{|c|}{$\begin{array}{l}92.8 \pm 1.8 \\
89.5-95.5\end{array}$} & $\begin{array}{l}\text { n.d. } \\
\text { n.d. }\end{array}$ & $\begin{array}{l}49.2 \pm 5.9^{c} \\
43.1-60.8\end{array}$ & $\begin{array}{l}62.1 \pm 14.6^{b} \\
43.6-83.7\end{array}$ \\
\hline \multirow[t]{4}{*}{ Juveniles } & $\begin{array}{l}10.3 \pm 0.1 \\
10.1-10.5\end{array}$ & 14 days & 5 & \multicolumn{2}{|c|}{$\begin{array}{l}10.4 \pm 1.7^{\mathrm{a}} \\
8.5-12.9^{-12}\end{array}$} & \multicolumn{2}{|c|}{$93.9 \pm 1.4$} & $\begin{array}{l}27.6 \pm 5.5 \\
19.7-34.5\end{array}$ & $\begin{array}{l}68.1 \pm 3.2^{b} \\
63.8-72.0\end{array}$ & $\begin{array}{l}50.0 \pm 17.2^{b} \\
33.0-77.4\end{array}$ \\
\hline & $\begin{array}{l}11.7 \pm 0.7 \\
10.9-12.7\end{array}$ & 1 month & 5 & \multicolumn{2}{|c|}{$\begin{array}{l}8.4 \pm 1.3^{\mathrm{ab}} \\
7.1-10.2\end{array}$} & \multicolumn{2}{|c|}{$93.6 \pm 1.4$} & $\begin{array}{l}25.4 \pm 4.7 \\
18.5-30.1\end{array}$ & $\begin{array}{l}68.5 \pm 3.5^{b} \\
64.2-72.1\end{array}$ & $\begin{array}{l}68.0 \pm 9.7^{a b} \\
57.9-79.1\end{array}$ \\
\hline & $\begin{array}{l}16.4 \pm 0.9 \\
15.0-17.4\end{array}$ & 1.5 months & 5 & \multicolumn{2}{|c|}{$\begin{array}{l}7.4 \pm 0.6^{b} \\
6.8-7.9\end{array}$} & & $\begin{array}{l} \pm 0.9 \\
-93.6\end{array}$ & $\begin{array}{l}30.7 \pm 3.3 \\
27.1-34.8\end{array}$ & $\begin{array}{l}74.9 \pm 2.0^{\mathrm{a}} \\
72.1-76.7\end{array}$ & $\begin{array}{l}\text { n.d. } \\
\text { n.d. }\end{array}$ \\
\hline & $\begin{array}{l}22.3 \pm 1.3 \\
21.3-22.6\end{array}$ & 2 months & 5 & \multicolumn{2}{|c|}{$\begin{array}{l}7.8 \pm 0.9^{\mathrm{ab}} \\
6.6-8.9\end{array}$} & \multicolumn{2}{|c|}{$\begin{array}{l}92.7 \pm 1.5 \\
90.3-94.3\end{array}$} & $\begin{array}{l}29.2 \pm 1.6 \\
28.2-31.2\end{array}$ & $\begin{array}{l}70.3 \pm 2.1^{\mathrm{b}} \\
66.8-72.5\end{array}$ & $\begin{array}{l}83.2 \pm 9.9^{\mathrm{a}} \\
67.0-92.3\end{array}$ \\
\hline Life stage & $\overline{\mathrm{Cu}}$ & $\mathrm{Fe}$ & $\mathrm{Mn}$ & & $\mathrm{Ni}$ & & $\mathrm{Pb}$ & $\mathrm{Se}$ & $\overline{Z n}$ & \\
\hline Hatchlings & $\begin{array}{l}27.3 \pm 11.8^{b} \\
11.0-39.8\end{array}$ & $\begin{array}{l}14.0 \pm 12.8^{\mathrm{c}} \\
2.4-37.4\end{array}$ & $\begin{array}{l}35.6= \\
22.5\end{array}$ & $\begin{array}{r}6.7 \\
4.4\end{array}$ & $\begin{array}{l}73.5 \\
56.9\end{array}$ & & $\begin{array}{l}\text { n.d. } \\
\text { n.d. }\end{array}$ & $\begin{array}{l}51.4 \pm 3.6^{\mathrm{b}} \\
46.5-56.3\end{array}$ & $\begin{array}{l}14.8 \pm 5.8^{b} \\
6.0-23.6\end{array}$ & \\
\hline Juveniles & $\begin{array}{l}41.3 \pm 7.5^{b} \\
31.2-51.9\end{array}$ & $\begin{array}{l}31.9 \pm 7.4^{\mathrm{b}} \\
25.6-42.8\end{array}$ & $\begin{array}{l}41.6= \\
37.1\end{array}$ & $\begin{array}{r}3.7 \\
45.0\end{array}$ & $\begin{array}{l}73.5 \\
67.9\end{array}$ & & $\begin{array}{l}79.3 \pm 2.8 \\
76.8-83.6\end{array}$ & $\begin{array}{l}62.0 \pm 3.6^{\mathrm{a}} \\
55.8-65.1\end{array}$ & $\begin{array}{l}18.4 \pm 2.9^{b} \\
15.6-22.3\end{array}$ & \\
\hline & $\begin{array}{l}40.8 \pm 6.2^{b} \\
33.8-49.7\end{array}$ & $\begin{array}{l}34.9 \pm 4.8^{b} \\
31.3-43.1\end{array}$ & $\begin{array}{l}41.3= \\
28.0\end{array}$ & $\begin{array}{c}8.5 \\
50.1\end{array}$ & $\begin{array}{l}77.0= \\
74.3\end{array}$ & & $\begin{array}{l}83.4 \pm 4.5 \\
79.0-87.5\end{array}$ & $\begin{array}{l}64.0 \pm 2.0^{\mathrm{a}} \\
62.1-66.9\end{array}$ & $\begin{array}{l}20.2 \pm 4.5^{b} \\
14.9-25.0\end{array}$ & \\
\hline & $\begin{array}{l}55.1 \pm 5.1^{\mathrm{a}} \\
47.3-61.0\end{array}$ & $\begin{array}{l}48.6 \pm 7.7^{\mathrm{a}} \\
37.8-55.9\end{array}$ & $\begin{array}{l}36.6= \\
22.8\end{array}$ & $\begin{array}{r}7.9 \\
+1.4\end{array}$ & $\begin{array}{l}78.6 \\
75.7\end{array}$ & & $\begin{array}{l}74.8 \pm 6.7 \\
69.1-85.8\end{array}$ & $\begin{array}{l}63.5 \pm 1.5^{\mathrm{a}} \\
60.9-65.1\end{array}$ & $\begin{array}{l}26.6 \pm 4.0^{\mathrm{ab}} \\
23.4-32.3\end{array}$ & \\
\hline & $\begin{array}{l}55.8 \pm 0.7^{\mathrm{a}} \\
55.1-56.8\end{array}$ & $\begin{array}{l}35.7 \pm 7.2^{a b} \\
24.6-44.0\end{array}$ & $\begin{array}{l}28.2= \\
21.0\end{array}$ & $\begin{array}{l}6.1 \\
37.1\end{array}$ & $\begin{array}{l}78.4 \\
77.3-\end{array}$ & & $\begin{array}{l}75.1 \pm 3.9 \\
69.4-80.2\end{array}$ & $\begin{array}{l}63.6 \pm 2.0^{\mathrm{a}} \\
60.5-66.0\end{array}$ & $\begin{array}{l}30.0 \pm 1.2^{\mathrm{a}} \\
28.6-31.7\end{array}$ & \\
\hline
\end{tabular}

The different letters denote for each trace element, statistically significant differences (at $p$-value < $0.05)$ between sampling times $(\mathrm{a} \neq \mathrm{b} \neq \mathrm{c})$. 
Table 3: Positive correlations between soluble concentrations of trace elements and metallothioneins measured in control juvenile cuttlefish between 2- and 8-week posthatching. Upright and italic scripts correspond to Pearson and Spearman correlations, respectively. Underlined: $p<0.001$; other: $p<0.05$.

\begin{tabular}{lll}
\hline Elements & \\
$\mathrm{Ag}$ & $+\mathrm{Cd}+\mathrm{Co}+\mathrm{Cu}+\mathrm{Zn}$ \\
$\mathrm{As}$ & $+\mathrm{Cr}+\mathrm{Fe}+\mathrm{Mn}+\mathrm{Ni}$ \\
$\mathrm{Cd}$ & $+\mathrm{Ag}+\mathrm{Co}+\mathrm{Cu}+\mathrm{Zn}$ \\
$\mathrm{Co}$ & $+\mathrm{Ag}+\mathrm{Cd}+\mathrm{Cu}+\mathrm{Fe}+\mathrm{Ni}+\mathrm{Pb}+\mathrm{Se}+\mathrm{Zn}$ \\
$\mathrm{Cr}$ & $+\mathrm{As}$ \\
$\mathrm{Cu}$ & $+\mathrm{Ag}+\mathrm{Cd}+\mathrm{Co}+\mathrm{Zn}+\mathrm{MTs}$ \\
$\mathrm{Fe}$ & $+\mathrm{As}+\mathrm{Co}+\mathrm{Mn}+\mathrm{Ni}$ \\
$\mathrm{Mn}$ & $+\mathrm{As}+\mathrm{Fe}+\mathrm{Ni}$ \\
$\mathrm{Ni}$ & $+\mathrm{As}+\mathrm{Co}+\mathrm{Fe}+\mathrm{Mn}+\mathrm{Se}$ \\
$\mathrm{Pb}$ & $+\mathrm{Co}$ \\
$\mathrm{Se}$ & $+\mathrm{Co}+\mathrm{Ni}$ \\
$\mathrm{Zn}$ & $+\mathrm{Ag}+\mathrm{Cd}+\mathrm{Co}+\mathrm{Cu}+\mathrm{MTs}$ \\
$\mathrm{MTs}$ & $+\mathrm{Cu}+\mathrm{Zn}$
\end{tabular}


Table 4: Positive correlations between insoluble concentrations of trace elements measured in control juvenile cuttlefish between 2- and 8-week post-hatching. Upright and italic scripts correspond to Pearson and Spearman correlations, respectively. Underlined: $p<0.001$; other: $p<0.05$.

\begin{tabular}{|c|c|c|c|}
\hline Elements & & & \\
\hline$\overline{\mathrm{Ag}}$ & $+\mathrm{Cd}$ & $+\mathrm{Co}+\mathrm{Pb}$ & \\
\hline As & $+\mathrm{Cr}$ & $+F e+N i$ & $+P b+S e$ \\
\hline $\mathrm{Cd}$ & $+\mathrm{Ag}$ & $+\mathrm{Co}+\mathrm{Cu}$ & $+Z n$ \\
\hline $\mathrm{Co}$ & $+\mathrm{Ag}$ & $+\mathrm{Cd}+\mathrm{Cu}$ & $+M n+Z n$ \\
\hline $\mathrm{Cr}$ & $+A s$ & $+F e+N i$ & $+\mathrm{Se}$ \\
\hline $\mathrm{Cu}$ & $\overline{+\mathrm{Cd}}$ & $\overline{+\mathrm{Co}}+\mathrm{Zn}$ & \\
\hline $\mathrm{Fe}$ & $+A s$ & $+\mathrm{Cr}+\mathrm{Mn}$ & \\
\hline Mn & $+C o$ & $+\mathrm{Fe}+\mathrm{Ni}$ & \\
\hline $\mathrm{Ni}$ & $+A s$ & $+\mathrm{Cr}+\mathrm{Mn}$ & \\
\hline $\mathrm{Pb}$ & $+\mathrm{Ag}$ & $+A s$ & \\
\hline $\mathrm{Se}$ & $+A s$ & $+\mathrm{Cr}$ & \\
\hline $\mathrm{Zn}$ & $+C d$ & $+\mathrm{Co}+\mathrm{Cu}$ & \\
\hline
\end{tabular}


Table 5: Zinc concentrations (mean $\pm \mathrm{SD}$ in $\mu \mathrm{g} \mathrm{l}^{-1}$ and $\mu \mathrm{M}$ ) in seawater during the experiment.

\begin{tabular}{lccc}
\hline Zn concentration & Control & Z1 & Z2 \\
\hline$\mu g 1^{-1}$ & $<6.2$ & $52 \pm 3$ & $184 \pm 11$ \\
$\mu \mathrm{M}$ & $<0.1$ & $0.80 \pm 0.05$ & $2.81 \pm 0.16$ \\
\hline
\end{tabular}


Table 6: Trace metal concentrations (mean $\pm \mathrm{SD}$ in $\mu \mathrm{g} \cdot \mathrm{g}^{-1} \mathrm{dw}$ ) in prey $(C$. crangon) used during this study.

\begin{tabular}{cc}
\hline $\mathrm{Fe}$ & $55.1 \pm 25.0$ \\
\hline $\mathrm{Zn}$ & $43.2 \pm 4.1$ \\
\hline $\mathrm{Cu}$ & $25.7 \pm 5.6$ \\
\hline $\mathrm{As}$ & $15.7 \pm 3.7$ \\
\hline $\mathrm{Mn}$ & $6.18 \pm 3.49$ \\
\hline $\mathrm{Se}$ & $2.33 \pm 0.73$ \\
\hline $\mathrm{Ni}$ & $1.56 \pm 0.60$ \\
\hline $\mathrm{Ag}$ & $0.99 \pm 0.13$ \\
\hline $\mathrm{Cd}$ & $0.25 \pm 0.08$ \\
\hline $\mathrm{Cr}$ & $0.23 \pm 0.18$ \\
\hline $\mathrm{Co}$ & $0.21 \pm 0.04$ \\
\hline $\mathrm{Pb}$ & $0.17 \pm 0.10$ \\
\hline $\mathrm{Hg}$ & $0.09 \pm 0.02$ \\
\hline $\mathrm{V}$ & $<0.39$ \\
\hline
\end{tabular}




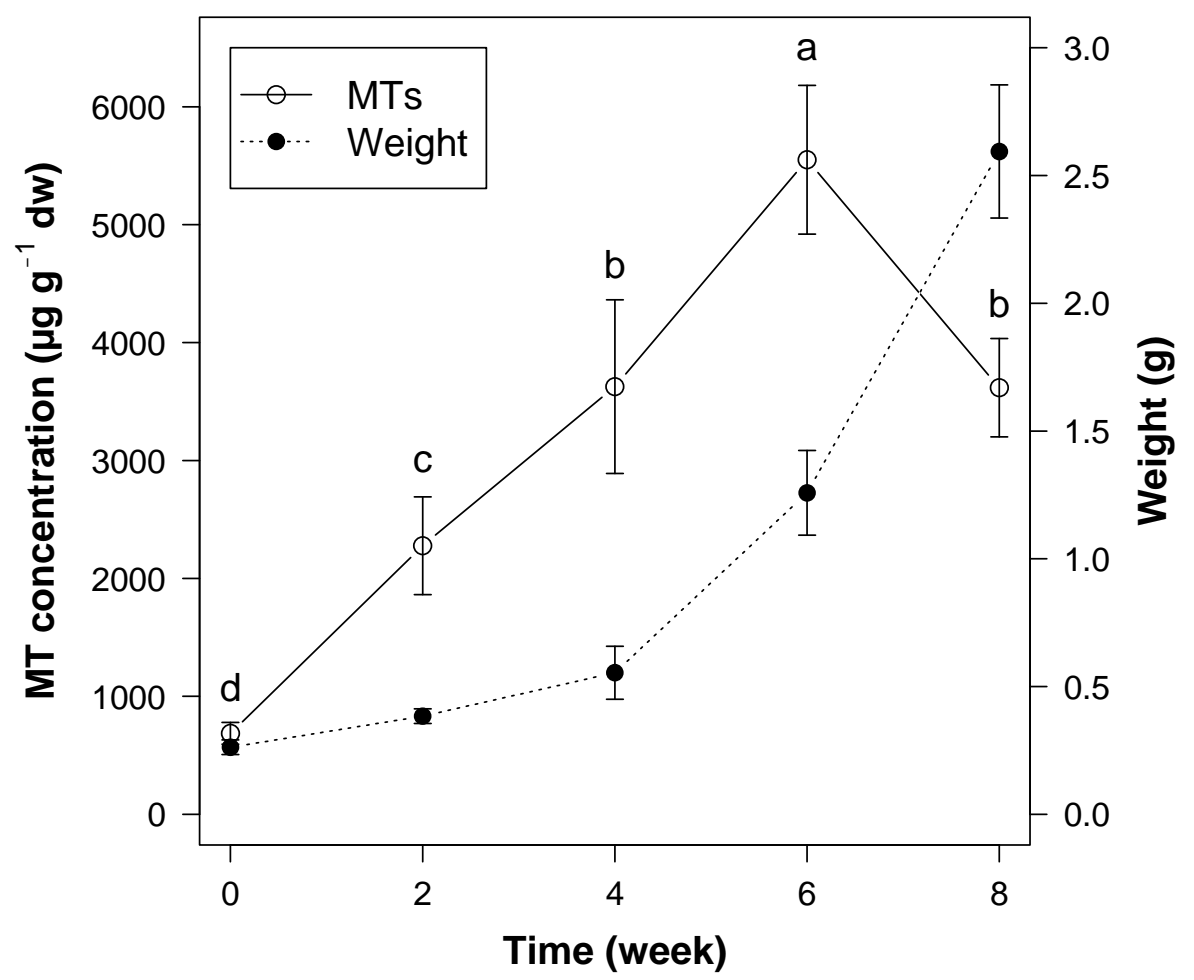

Figure 1: Metallothionein concentrations (mean $\pm \mathrm{SD} ; \mu \mathrm{g} \mathrm{g}^{-1} \mathrm{dw}$ ) in juvenile cuttlefish and associated weight (mean $\pm \mathrm{SD}$; g) during the 2 months post-hatching. Letters above the metallothionein concentrations indicate significant differences between groups ( $p$-value < $0.05)$. 


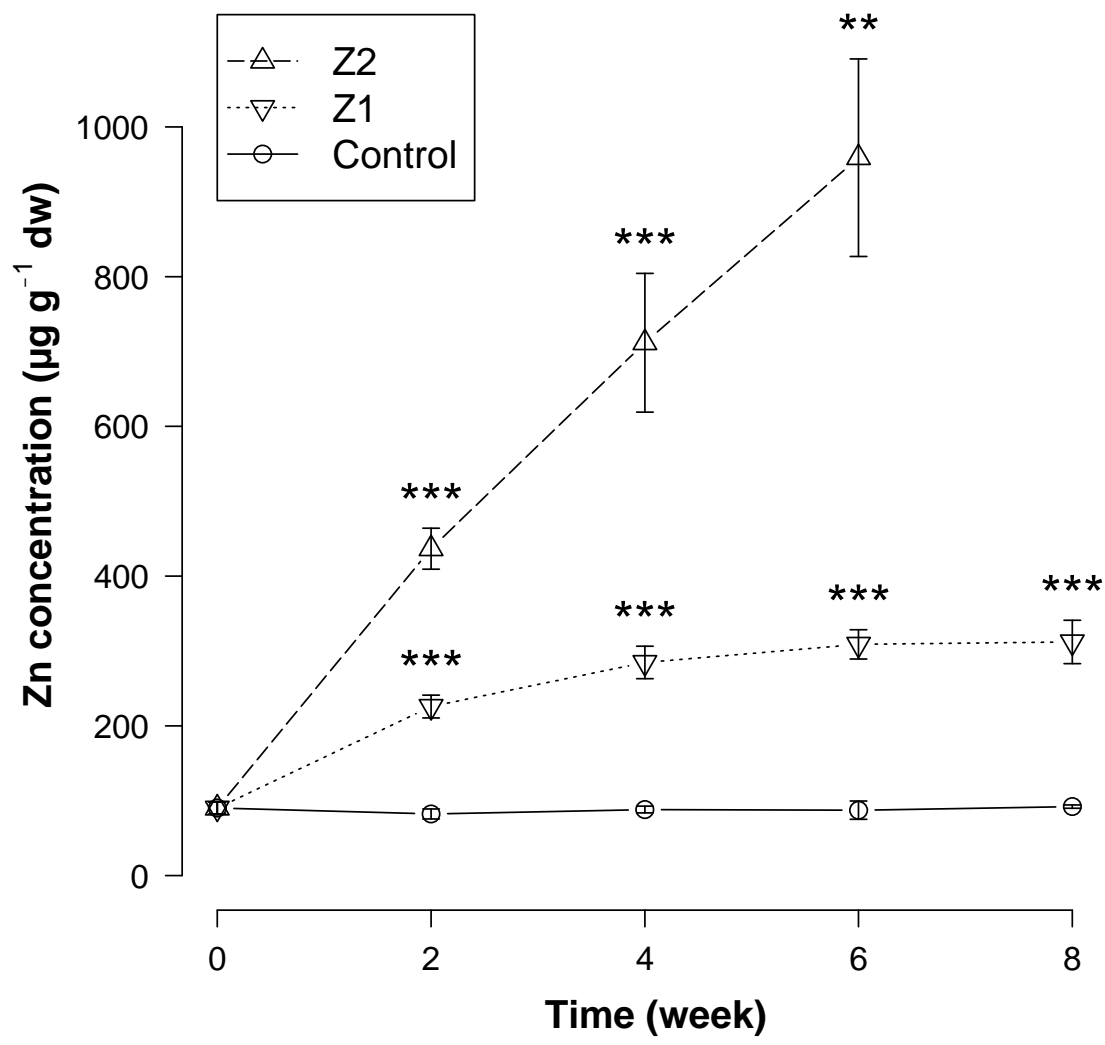

Figure 2: Total $\mathrm{Zn}$ concentrations (mean $\pm \mathrm{SD} ; \mu \mathrm{g} \mathrm{g}{ }^{-1} \mathrm{dw}$ ) in juvenile cuttlefish reared in control and in $2 \mathrm{Zn}$ concentrations $(\mathrm{Z1}, \mathrm{Z2})$. Asterisks correspond to significant differences compared to control $(*<0.05, * *<0.01, * * *<0.001)$. 


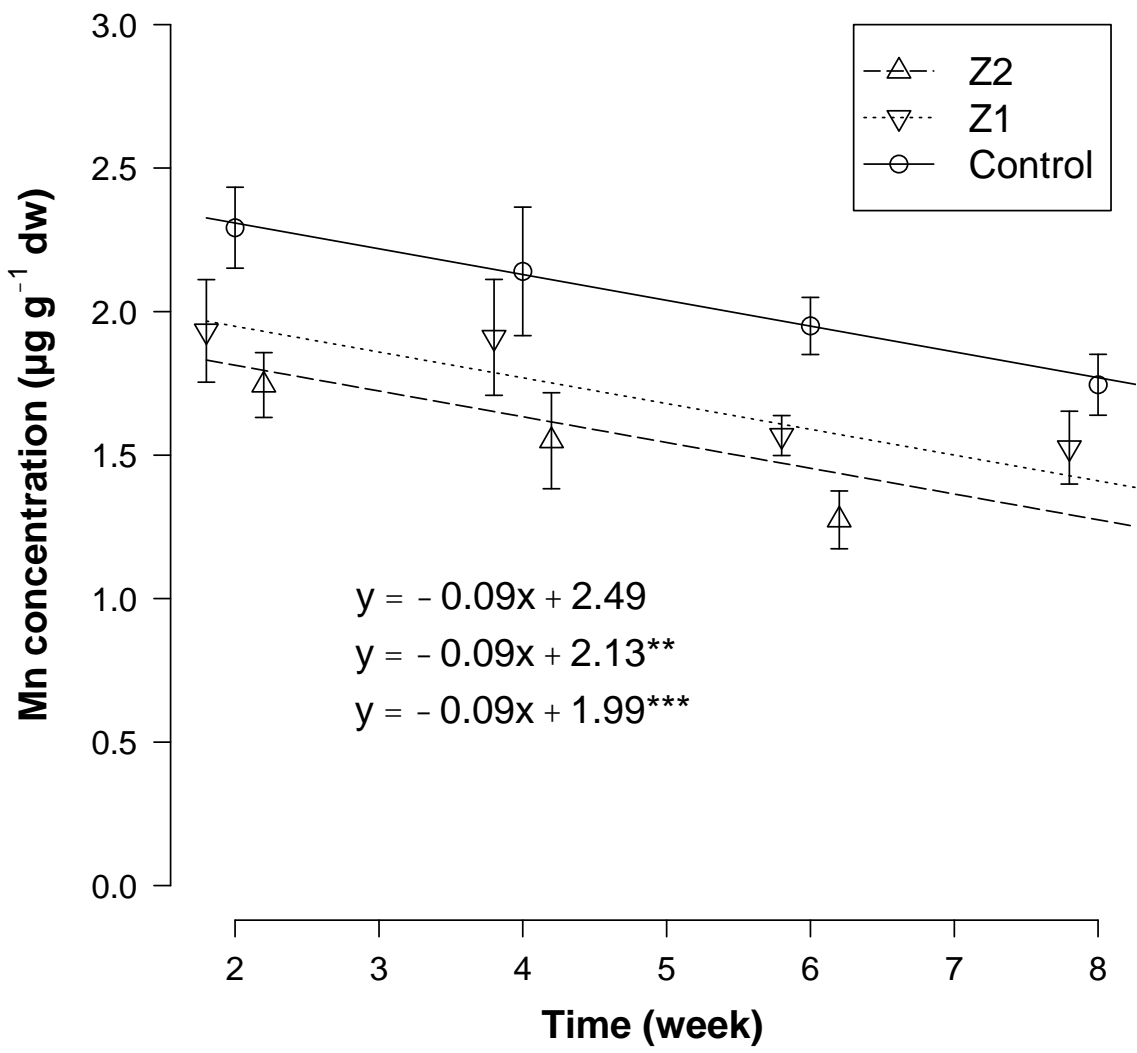

Figure 3: Total Mn concentrations (mean $\pm \mathrm{SD} ; \mu \mathrm{g} \mathrm{g}{ }^{-1} \mathrm{dw}$ ) in juvenile cuttlefish reared in control and in two $\mathrm{Zn}$ concentrations $(\mathrm{Z1}, \mathrm{Z} 2)$. Asterisks correspond to significant differences compared to control $(* *<0.01, * * *<0.001)$. 

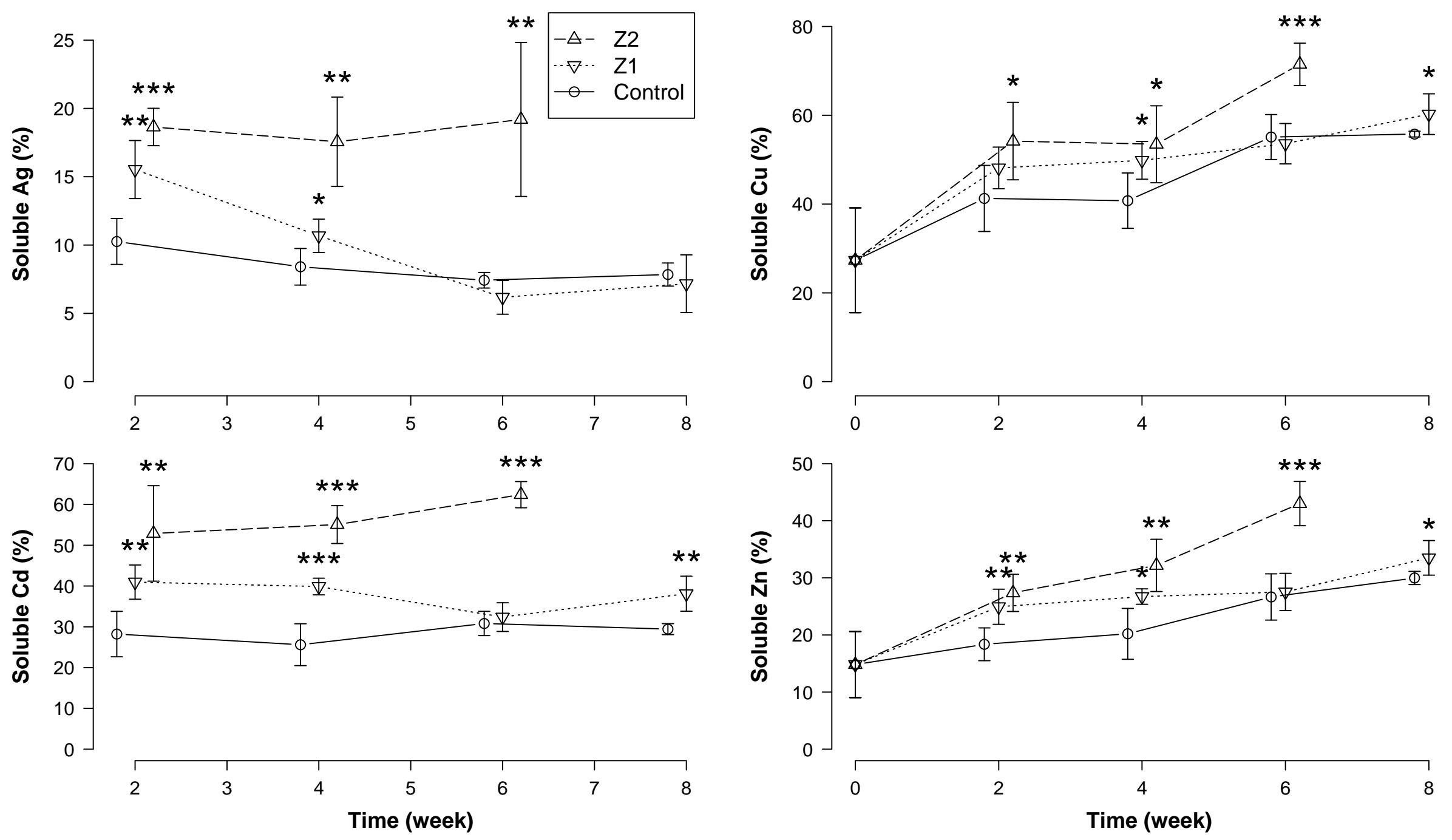

Figure 4: Soluble $\mathrm{Ag}, \mathrm{Cd}, \mathrm{Cu}$ and $\mathrm{Zn}$ proportions (mean $\pm \mathrm{SD}$; \%) in juvenile cuttlefish reared in control and in $2 \mathrm{Zn}$ concentrations $(\mathrm{Z1}$, Z2). Asterisks correspond to significant differences compared to control $(*<0.05$, $* *<0.01$, $* * *<0.001)$. 


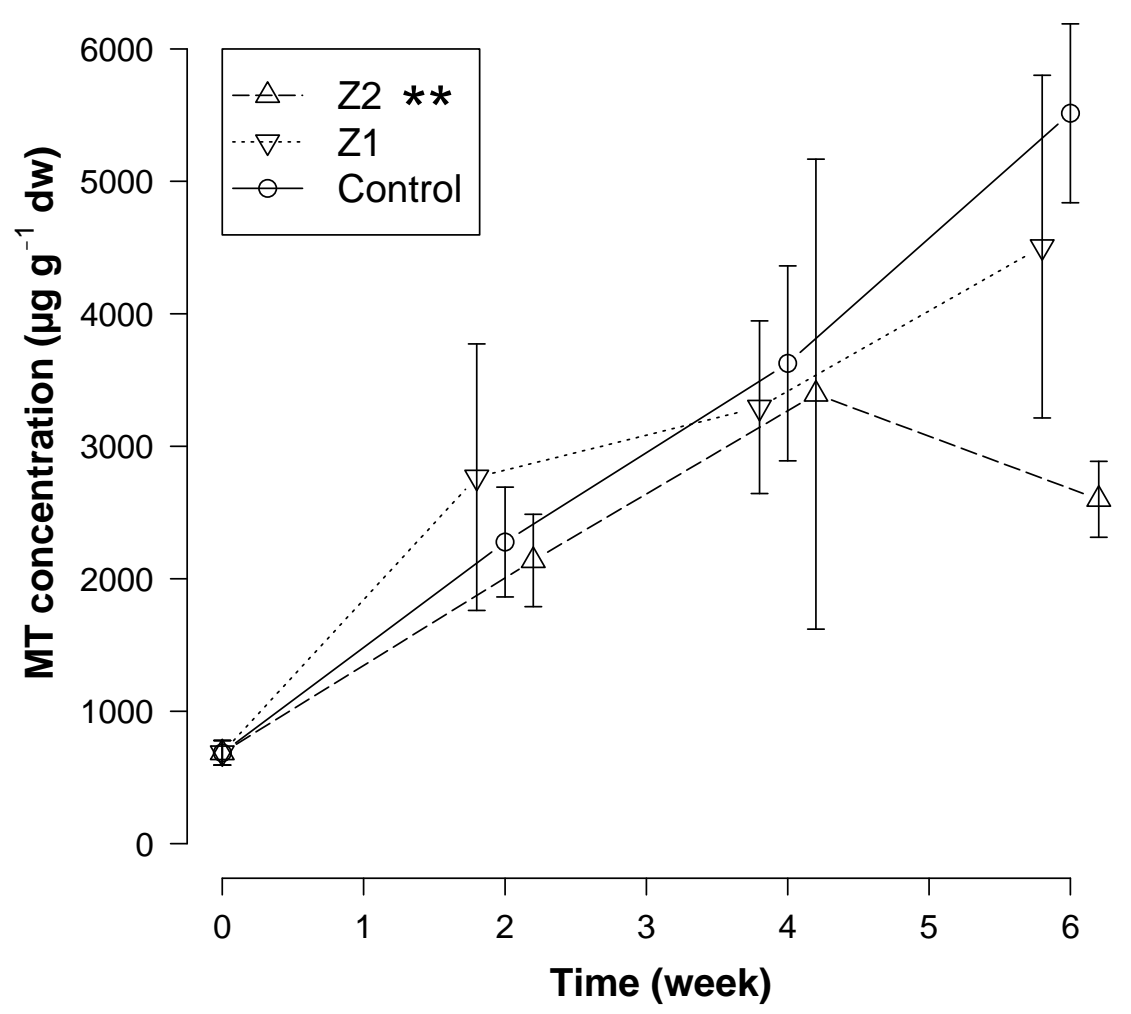

Figure 5: Metallothionein concentrations (mean $\pm \mathrm{SD} ; \mu \mathrm{g} \mathrm{g}^{-1} \mathrm{dw}$ ) in juvenile cuttlefish reared in control and in $2 \mathrm{Zn}$ concentrations (Z1, Z2) during 6 week post-hatching. Asterisks correspond to significant differences of metallothionein changes over time compared to control (i.e. different slopes; $* *<0.01$ ). 

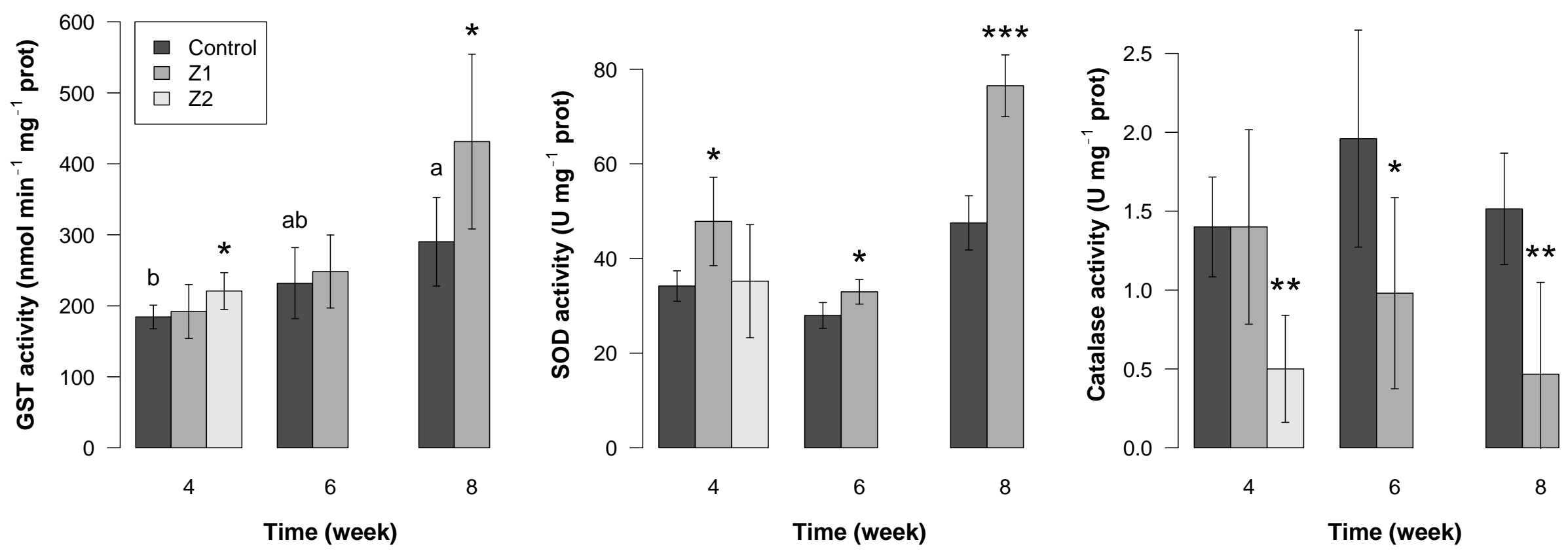

Figure 6: Glutathione S-transferase, superoxide dismutase and catalase activities (mean $\pm \mathrm{SD}$; respectively in $\mathrm{nmol} \mathrm{min}^{-1} \mathrm{mg}^{-1} \mathrm{prot} \mathrm{U} \mathrm{mg}^{-1} \mathrm{prot}_{\text {, }}$ and $\mathrm{U} \mathrm{mg}^{-1}$ prot) in the digestive gland of juvenile cuttlefish in control, Z1 and Z2 conditions after 4-week post-hatching and in control and Z1 conditions after 6- and 8-week post-hatching. Letters above control indicate its change over time, and asterisks above Z1 or Z2 correspond to significant differences of activity compared to control $(*<0.05, * *<0.01)$. 


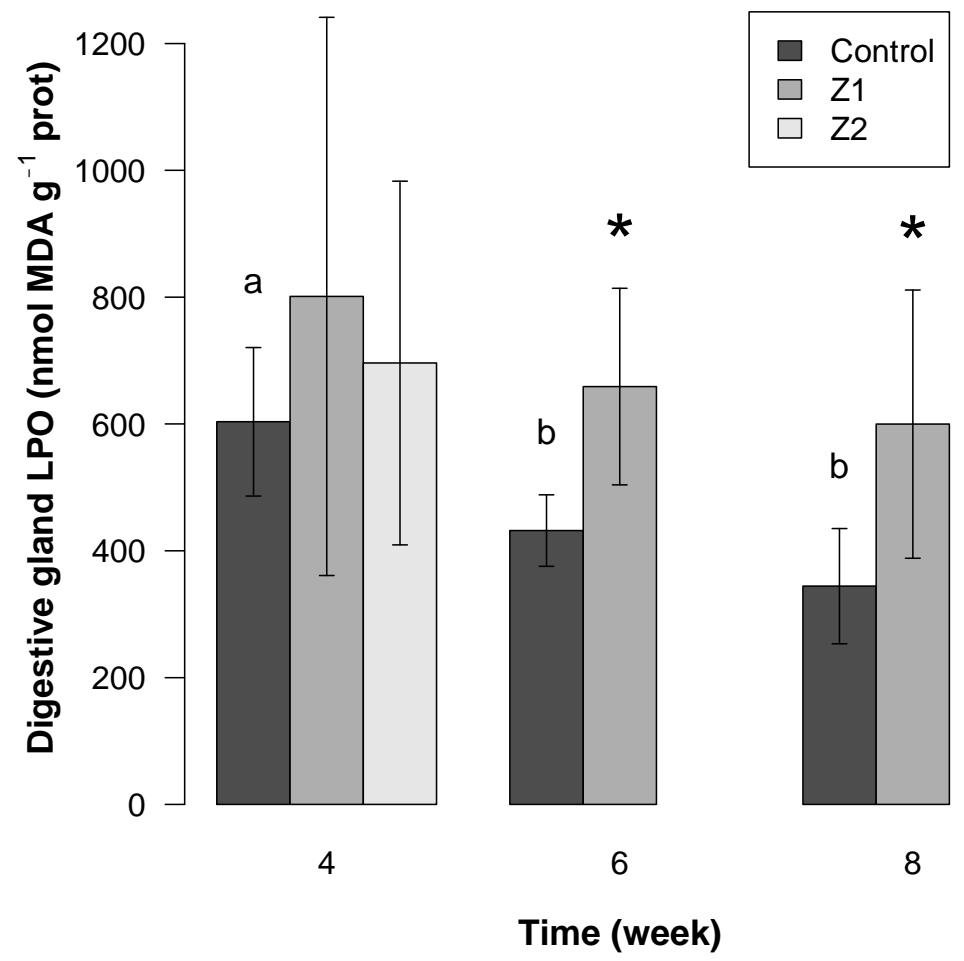

Figure 7: Lipid peroxidation (mean $\pm \mathrm{SD}$; nmol MDA $\mathrm{g}^{-1}$ prot) in the digestive gland of juvenile cuttlefish in control, Z1 and Z2 conditions after 4-week post-hatching and in control and Z1 conditions after 6- and 8-week post-hatching. Letters above control indicate its change over time, and asterisks above Z1 correspond to significant differences of activity compared to control $(*<0.05)$. 